\title{
Perceptions of students and teachers regarding agriculture in Leflore County, Mississippi
}

\author{
Ronald L. Howard \\ West Virginia University
}

Follow this and additional works at: https://researchrepository.wvu.edu/etd

\section{Recommended Citation}

Howard, Ronald L., "Perceptions of students and teachers regarding agriculture in Leflore County, Mississippi" (1999). Graduate Theses, Dissertations, and Problem Reports. 977.

https://researchrepository.wvu.edu/etd/977

This Thesis is protected by copyright and/or related rights. It has been brought to you by the The Research Repository @ WVU with permission from the rights-holder(s). You are free to use this Thesis in any way that is permitted by the copyright and related rights legislation that applies to your use. For other uses you must obtain permission from the rights-holder(s) directly, unless additional rights are indicated by a Creative Commons license in the record and/ or on the work itself. This Thesis has been accepted for inclusion in WVU Graduate Theses, Dissertations, and Problem Reports collection by an authorized administrator of The Research Repository @ WVU. For more information, please contact researchrepository@mail.wvu.edu. 
Perceptions of Students and Teachers Regarding Agriculture in Leflore County, Mississippi

Ronald L. Howard

Thesis submitted to the College of Agriculture, Forestry, and Consumer Sciences

at West Virginia University in partial fulfillment of the requirements

for the degree of

\author{
Master of Science \\ in \\ Agricultural Education
}

Layle D. Lawrence, Ph.D., Chair

Gary J. Wingenbach, Ph.D

Stacy A. Gartin, Ph.D

Division of Resource Management

Morgantown, West Virginia

1999

Keywords: Agriculture, Careers, Education 


\section{ABSTRACT \\ Perceptions of Students and Teachers Regarding Agriculture in Leflore County, Mississippi}

\section{Ronald L. Howard}

The purpose of this study was to assess the perceptions of public high school teachers and students in Leflore County, Mississippi regarding agriculture and provide baseline data regarding the perception of high school students and teachers residing in an agriculturally dependent county with no agricultural education program. A population of 240 high school teachers and students was surveyed for their perceptions regarding agriculture. All three public high schools in Leflore County were represented in this study. Over $65 \%$ of the sample resided in the city, while only $3 \%$ live on a farm. The major finding of this study was that teachers and students perceived agriculture as being important and relative to their existence. Although a positive perception of agriculture exists among students, students have no intentions on studying or pursuing a career in agriculture. 


\section{DEDICATION}

In loving memory of Leslie Ware, Jr., a true soldier, your light will forever shine within me.

To my Three Angels, Virginia, Audrea, and Regina, who give me spirit and motivation. I love you.

To Shania and "The New Baby", I look forward to seeing you grow and prosper. 


\section{ACKNOWLEDGMENTS}

First and foremost, the writer gives praise to God for his guidance and protection. His blessings provided me with the motivation and discipline to complete this research.

The writer wishes to express his appreciation to the administration and students in Amanda Elzy, Leflore County, and Greenwood High Schools for participating in this study.

To Dr. Lawrence, thank you for your time, patience, and advice. Your wisdom and support helped to make my climb to the top of the mountain easier.

To Dr. Wingenbach, my favorite professor thanks for pushing me that extra mile when I thought I had gone far enough. I am grateful for the opportunity to learn from you. Your interest in my work has definitely made me a better student and educator.

To Dr. Schaeffer, I sincerely appreciate your efforts in helping me adjust to my new academe, and for providing me with extra instructions and assistance.

To Dr. Gartin, thanks for reviewing my work and providing me with excellent advice.

To my, family and friends, for encouraging and supporting me in my quest to take my place in society. Thank you for your undying love. I love you all.

To Stephanie, the road would have been considerably longer and difficult without you. Thank you for your patience, friendship, and love. God bless you!

To The Jackson and Carpenter Family for providing me with a home away from home. Thank you for your love and support. You will always be remembered.

A special thanks to: Bob, Lauren, Brooke, Isaac, Roseanne, and Brian, thanks for the support and words of encouragement. May peace be with you. 


\section{TABLES OF CONTENTS}

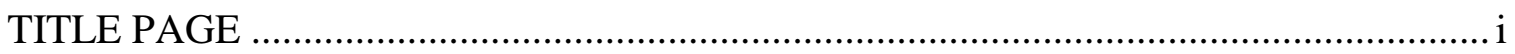

ABSTRACT ......................................................................................................

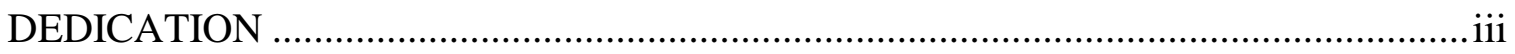

ACKNOWLEDGMENTS ................................................................................... iv

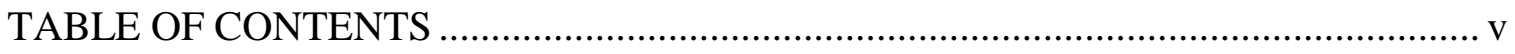

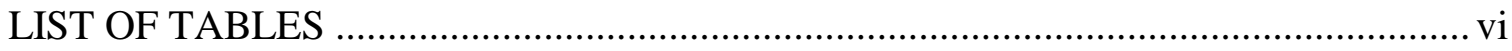

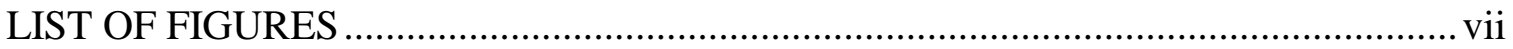

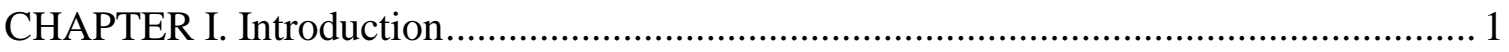

Statement of the Problem ................................................................................... 7

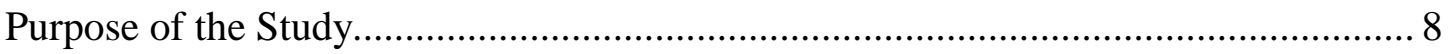

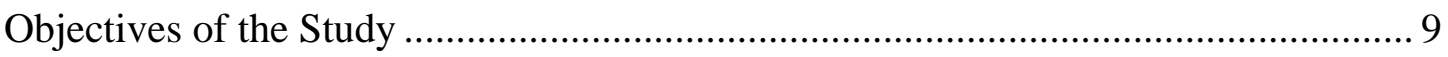

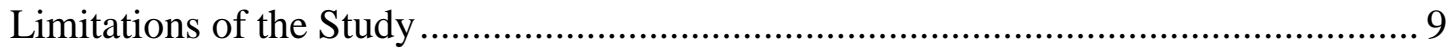

CHAPTER II. Review of Literature ......................................................................... 10

The General Public's Perception of Agriculture .................................................. 10

Students' Perceptions of Agriculture ................................................................ 10

Common Misconceptions Regarding Agriculture............................................... 11

Guidance Counselors' and Teachers' Roles in Students Career Choices ............. 12

Importance of Agricultural Literacy .................................................................... 12

The Role of Agriculture Education ................................................................. 13

Impact of Educational Reform ......................................................................... 14

Factors Influencing Students to Participate in Agriculture Programs ................... 14

Summary of Related Literature ………........................................................... 15

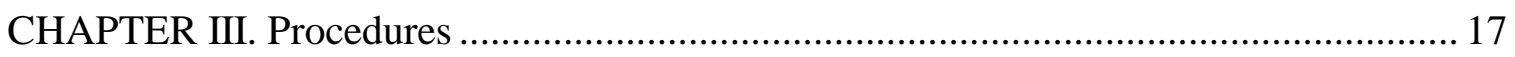

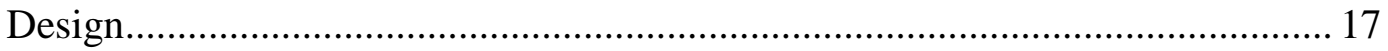

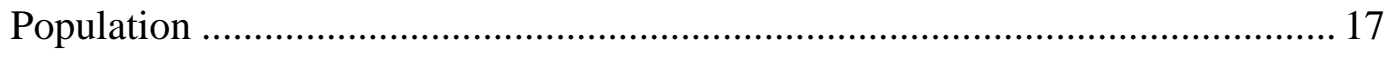

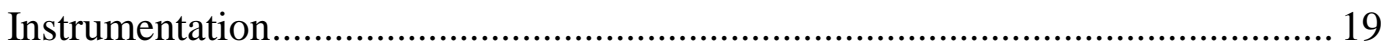

Data Collection Procedures .............................................................................. 18

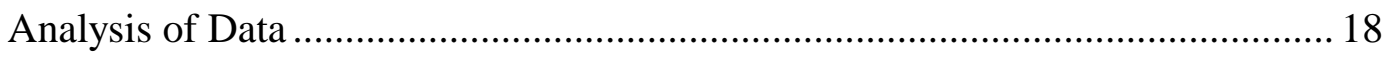




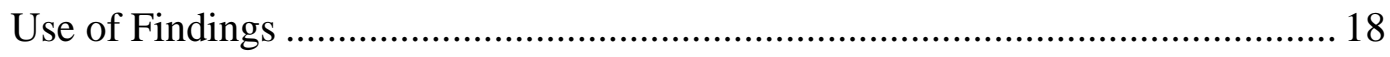

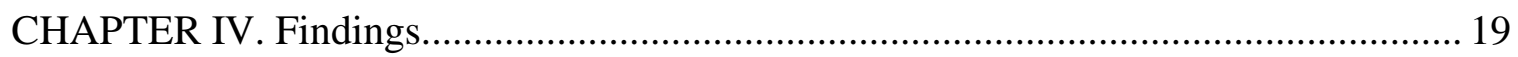

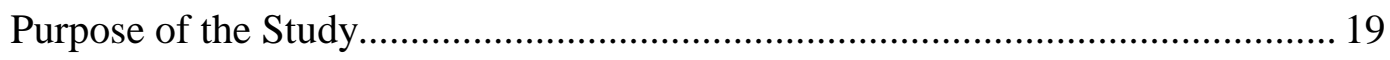

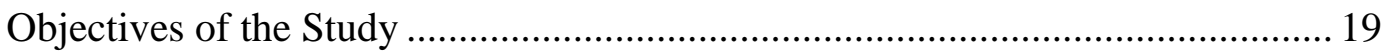

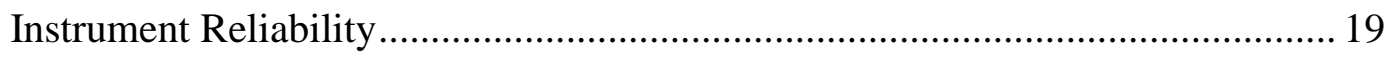

Description of Respondents ....................................................................... 20

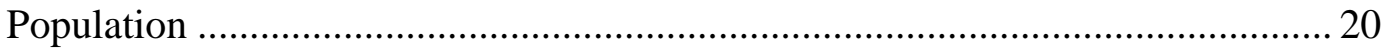

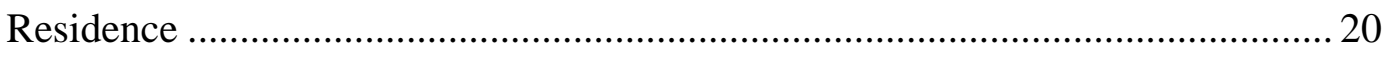

Experience in Agricultural Related Work .............................................................. 20

Relative with Agricultural Related Experience.................................................... 20

Ethnicity .................................................................................................... 22

Mean Responses for Individual Perception Statements ....................................... 22

Comparison of Perceptions Between Teachers and Students ………………….... 25

Comparison of Perceptions by Gender.................................................................. 27

Comparison of Perceptions of Students and Teachers by Schools........................ 28

Comparison of Perceptions Between Students by School...................................... 29

Comparison of Perceptions Between Students by Gender..................................... 30

Comparison of Perceptions Between Teachers by Schools .................................... 31

Comparison of Perceptions Between Teachers by Gender ...................................... 32

Comparison of Perceptions Among Students Who Had and Had Not Done

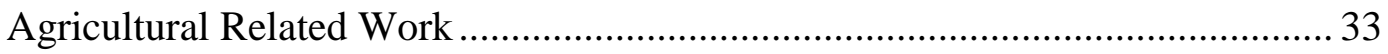

Comparison of Perceptions Among Teachers Who Had and Had Not Done

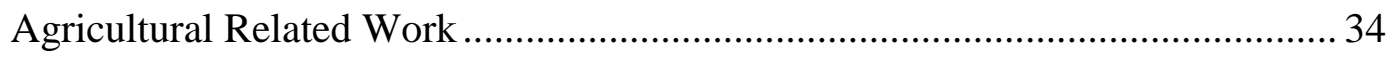

Comparison of Perceptions Among Students That Have and Did Not Have

Relatives Who Had Done Agricultural Related Work ............................................ 35

Comparison of Perceptions Among Teachers That Have and Did Not Have

Relatives Who Had Done Agricultural Related Work ............................................ 36

Comparison of Perceptions of Teachers by Ethnicity ............................................ 37

V. Summary, Conclusions, and Recommendations ......................................................... 38

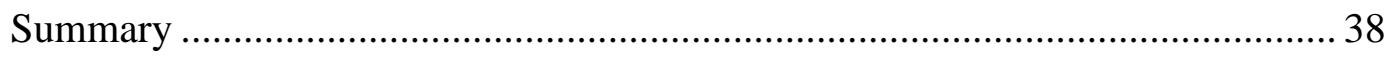




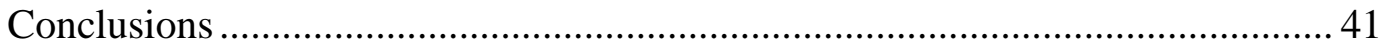

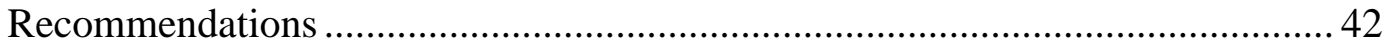

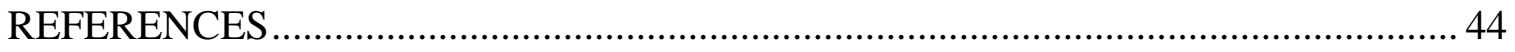

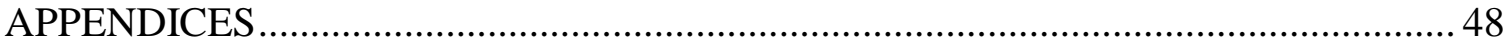

APPENDIX A: Letter to the High School Principals...................................... 49

APPENDIX B: Follow-up Letter to the High School Principals ........................ 53

APPENDIX C: Cover Letter to Participants and Parents...................................... 56

APPENDIX D: Cover Letter to Participants ..................................................... 59

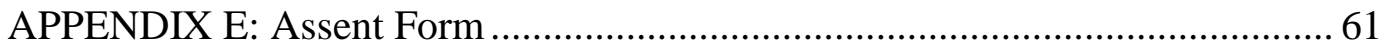

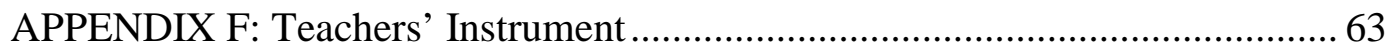

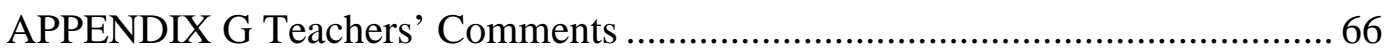

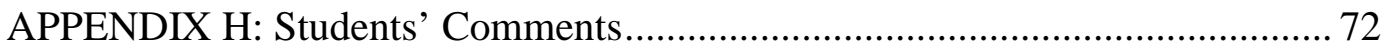

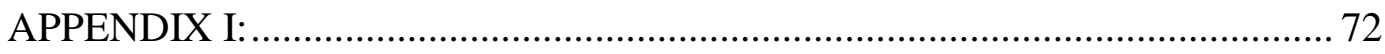

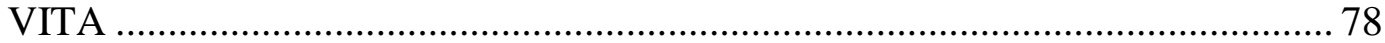




\section{LIST OF TABLES}

Page

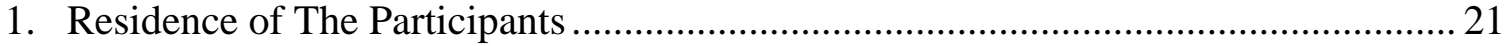

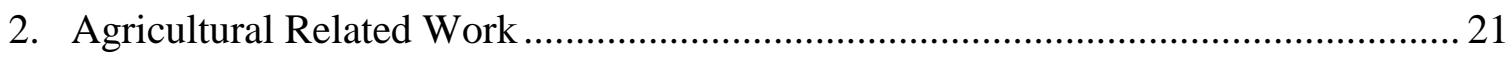

3. Relatives With Agricultural Related Experience ............................................... 22

4. Participants' Ethnic Background .............................................................................. 22

5. Means And Standard Deviations For Individual Perception Statements ................... 24

6. Teachers and Students Ratings for Individual Perception Statements ...................... 26

7. Perceptions of Students and Teachers by Gender .............................................. 27

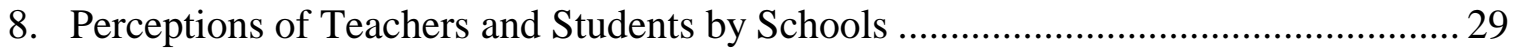

9. Comparison of Perceptions among Students by Schools ......................................... 30

10. Comparison of Perceptions among Students for Individual Statements .................... 31

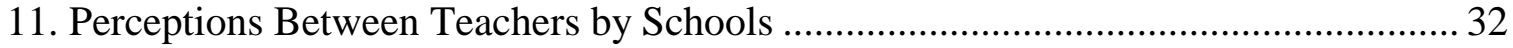

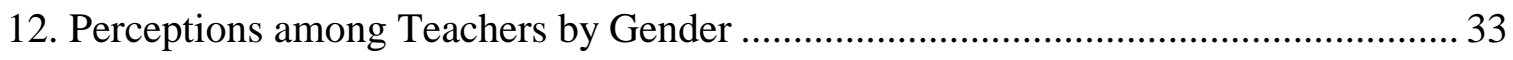

13. Perceptions of Students Who Had and Had Not Done Agriculture Related Work ..... 34

14. Perceptions of Teachers Who Had and Had Not Done Agriculture Related Work .... 34

15. Comparison of Perceptions among Students That Have and Did Not Have Relatives Who Had Done Agricultural Related Work ........................................................... 35

16. Perceptions of Teachers That Have and Did Not Have Relatives Who Had Done

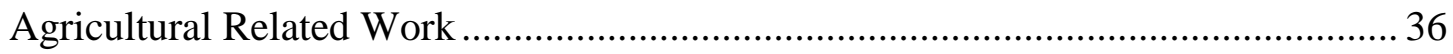

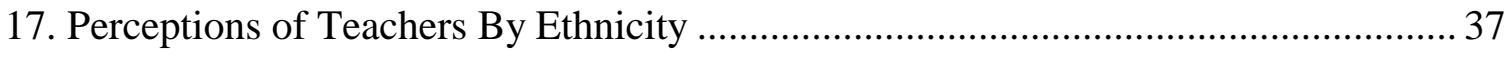




\section{LIST OF FIGURES}

Page

1. USDA Employees by Race in Mississippi ...................................................... 2

2. USDA Employees by Race in Leflore County .................................................... 3

3. Distribution of Agriculture in Leflore County, Mississippi ...................................... 4

4. Agriculture Census Data: Number of Farms ........................................................... 6

5. Agriculture Census Data: Acres of Land In Farms ............................................. 6

6. Value of Production of Specific Crops in Leflore County ....................................... 7 


\section{CHAPTER I}

\section{INTRODUCTION}

The word agriculture is derived from two Latin words: agri, meaning field; and cultura, to cultivate. Cultivating crops in fields or orchards is the essence of agriculture. The raising of livestock, making of dairy products, and poultry farming is also an integrate part of the science of agriculture. Cultivated land occupies only $11 \%$ of the world's land resources, but produces about $95 \%$ of the food for the world's people. Agriculture is the very basis of civilization and essential for our existence. Our food, clothing, homes, even our traditions and values all come from agriculture.

Scientific research is particularly important to today's agriculture, as are management and financial skills for the care of crops and livestock. The agriculture industry includes the agribusinesses that supply inputs such as herbicides and fertilizers, food processors, and marketers that shift production to local and global consumption.

Agricultural production takes up $80 \%$ of the countryside. It is therefore of paramount importance that those people who want to manage and conserve the countryside have a thorough knowledge and understanding of both agriculture and the people who work in it (Whitworth, 1998). Men and women of all ages and ethnic groups have a vested interest in agriculture (Law and Pepple, 1990). We rely on farmers to combine their roles of food producers and countryside stewards to protect and conserve vast areas of our land.

For the first time in our history, a vast majority of the population is more than one generation removed from agriculture. No longer do most children have a grandparent or close relative who is a farmer or rancher. As a result, most Americans know little about food and fiber production, its social and economic significance in the United States, and its links to human health and environmental quality. The agriculture industry is so efficient that only two percent of the country's population is involved directly in production agriculture but produces about $17 \%$ of the U.S. Gross National Product. Because Americans spend only ten percent of their total income on food, we are able to enjoy a high standard of living (Raven, 1994).

A 1990 study by the United States Department of Agriculture (USDA) showed that within the next five to ten years as many as 48,000 job opportunities will be available 
each year to college graduates in agricultural and food sciences, natural resources, and related areas. Conversely, the study showed that there will be a shortage of graduates needed to fill these jobs. It was suggested that there will be a shortage of 5,000 graduates per year to fill these vacancies.

USDA also indicated that a critical shortage will occur in the number of minority students educated in agriculturally related fields (Brown, 1994). Minorities are currently caught in a struggle to maintain and regain an equal footing in our society and work place that has been eroding over the past ten years. A dynamic resurgence has taken place in the United States Department of Agriculture to renew efforts for equal opportunity.

Figures 1 and 2 illustrate the underrepresentation of Blacks in Leflore County and Mississippi's branches of USDA (USDA, 1997). Figure 3 shows the distribution of agricultural employees in Leflore County.

\section{USDA Employment Statistics}

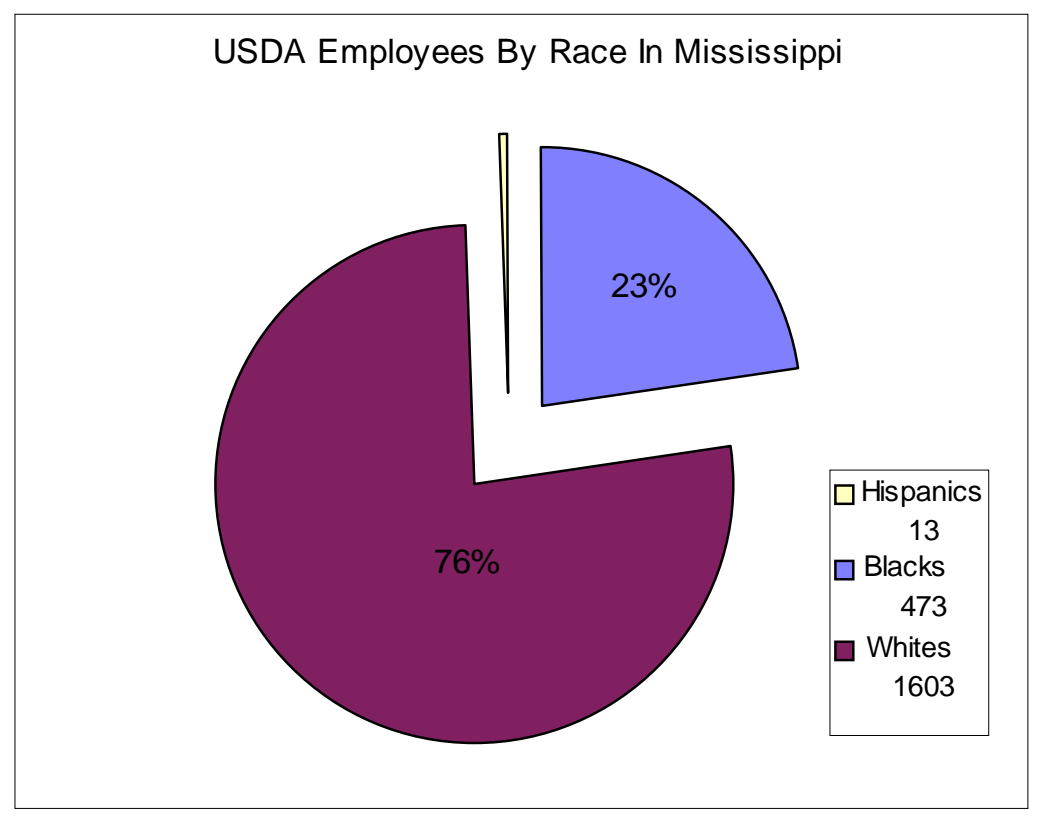

Figure 1 


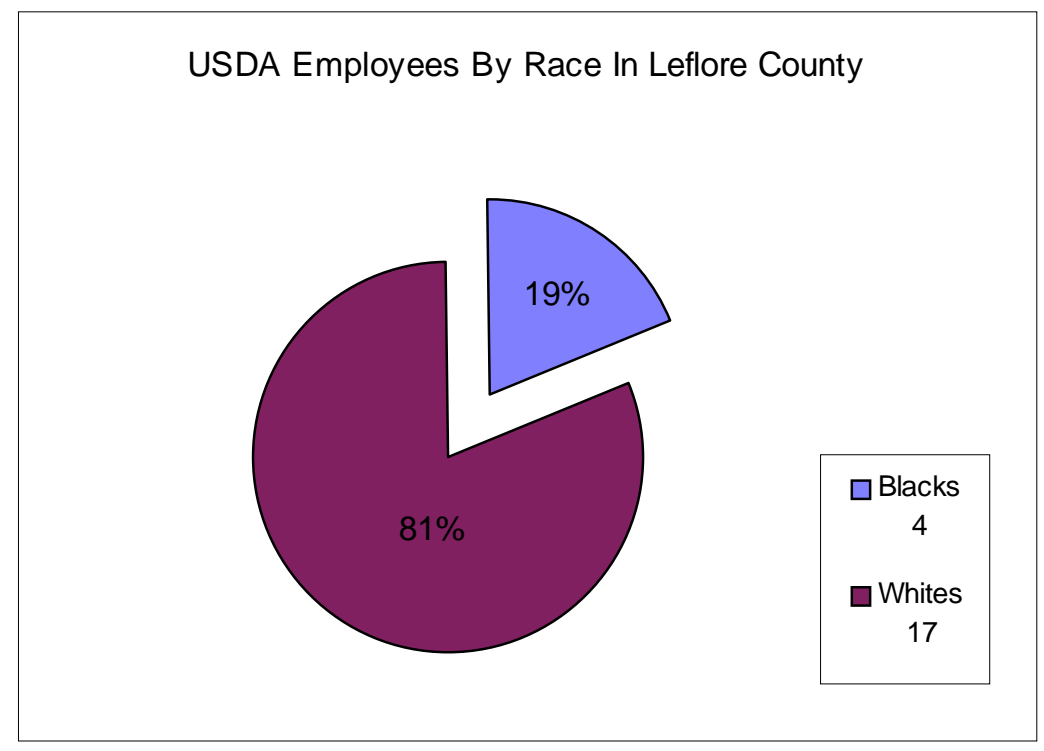

Figure 2 
Distribution of Agriculture Employees in Leflore County, Mississippi

\begin{tabular}{llll}
\hline Category & Whites & Blacks & Total \\
\hline Farmers: & 102 & 41 & 143 \\
Male & 0 & 15 & 15 \\
Female & & & \\
$\begin{array}{l}\text { Farm managers: } \\
\text { Male }\end{array}$ & 87 & 37 & 124 \\
Supervisors, farm workers: & & & \\
Male & 17 & 6 & 23 \\
Farm workers: & & & \\
Male & 78 & 406 & 484 \\
Female & 4 & 31 & 35 \\
$\begin{array}{l}\text { Supervisors, agricultural related occupations: } \\
\text { Male }\end{array}$ & 5 & 0 & 5 \\
$\begin{array}{l}\text { Groundskeepers and gardeners, except farm: } \\
\text { Male }\end{array}$ & & & \\
Animal caretakers, except farm: & 15 & 79 & 94 \\
Male & & & \\
Graders and sorters, agricultural products: & & 7 & 7 \\
$\begin{array}{l}\text { Male } \\
\text { Female }\end{array}$ & 14 & 0 & 14 \\
$\begin{array}{l}\text { Supervisors, forestry and logging workers: } \\
\text { Male }\end{array}$ & 0 & 4 & 4 \\
$\begin{array}{l}\text { Timber cutting and logging occupations: } \\
\text { Male }\end{array}$ & 5 & 0 & 5 \\
$\begin{array}{l}\text { Fishers: } \\
\text { Male }\end{array}$ & 10 & 0 & 10 \\
\hline & 6 & 15 & 21 \\
\hline
\end{tabular}

Figure 3 
How students perceive the agricultural industry and its career potential is critical to the future of agriculture. Students' career choices may influence the quality and quantity of available agriculturists well into the next century.

Agriculture around the world produces a vast array of products. The kinds of crops and animals produced depend mainly on climate and soil conditions, but are influenced strongly by local customs and market possibilities.

Agriculture is Mississippi's number one industry, employing over 30\% of the state's workforce either directly or indirectly. Agriculture in Mississippi is a 4.9 billion-dollar industry. There are approximately 43,000 farms in the state covering 13 million acres. Agriculture makes a significant contribution to all of the 82 counties in Mississippi. Leflore County was created in 1871 from Carroll, Sunflower, and Tallahatchie counties. The county is located within the Mississippi Delta Region where cotton and catfish are plentiful. Agriculture Census Land Use Data for Leflore County are indicated in Figure 5 and 5. Mississippi ranks third behind California and Texas in cotton production. In 1997, the average yield of cotton was 869 pounds per acre. There were 97, 000 acres planted, producing 1.81 million bales. Eighty percent of all catfish produced in the United States comes from the Mississippi Delta. There are approximately 500 catfish producers across Mississippi, and over 100,000 water acres are devoted to channel catfish production. There are 15 catfish processing plants in Mississippi.

Greenwood, the county seat, is the largest city in Leflore County. Located along the Delta's eastern border, Greenwood is known across the country as the "Cotton Capital of the World." Fertile acres of productive agricultural land stretches for mile after mile. An additional attraction in the Greenwood area includes vast acres of catfish farms.

Ranking of crops based on production value for Leflore County is illustrated in Figure 6. 
Agriculture Census for Leflore County, Mississippi, and the United States

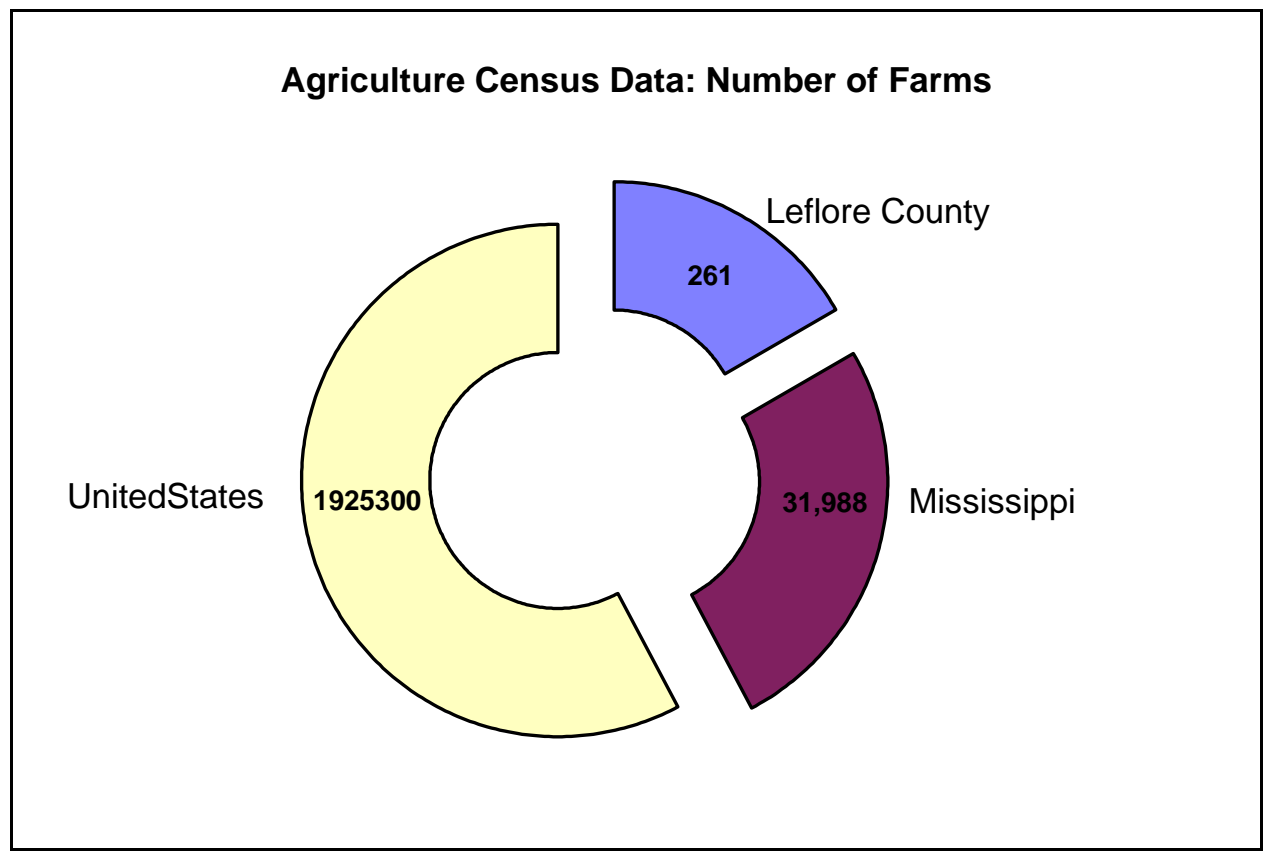

Figure 4

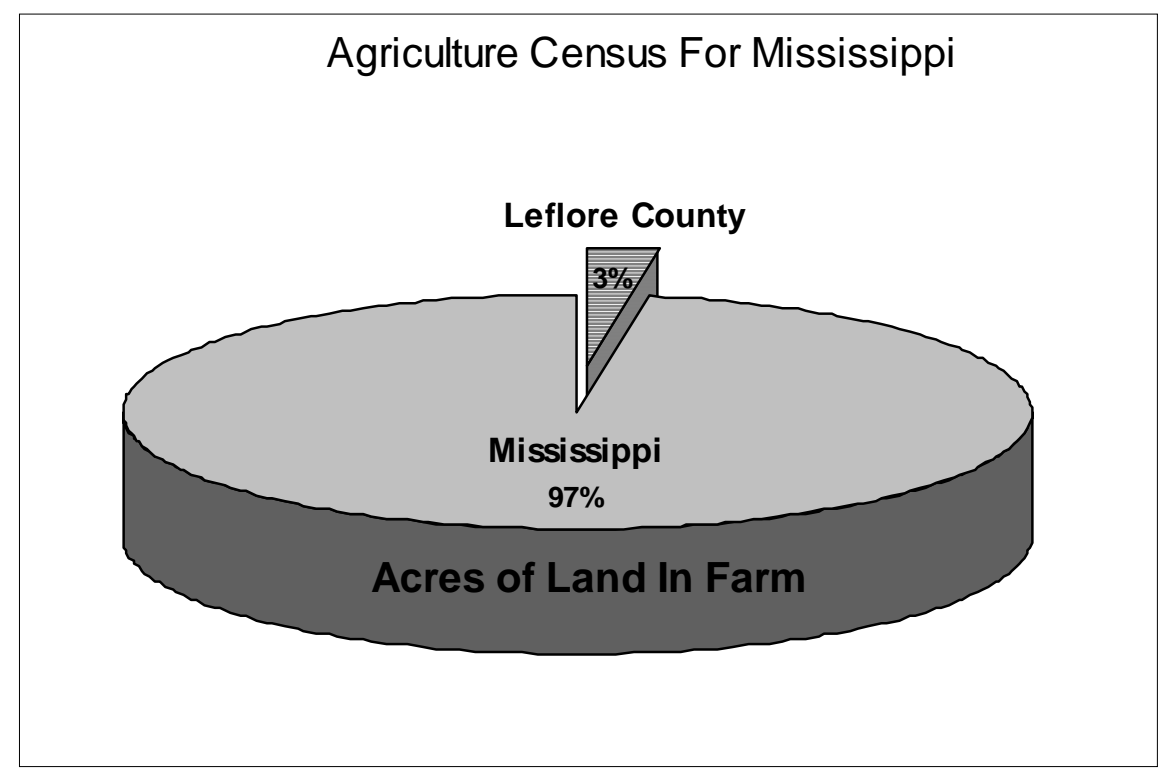

Figure 5 
$\underline{\text { Ranking and Value of Agriculture Production in Leflore, County }}$

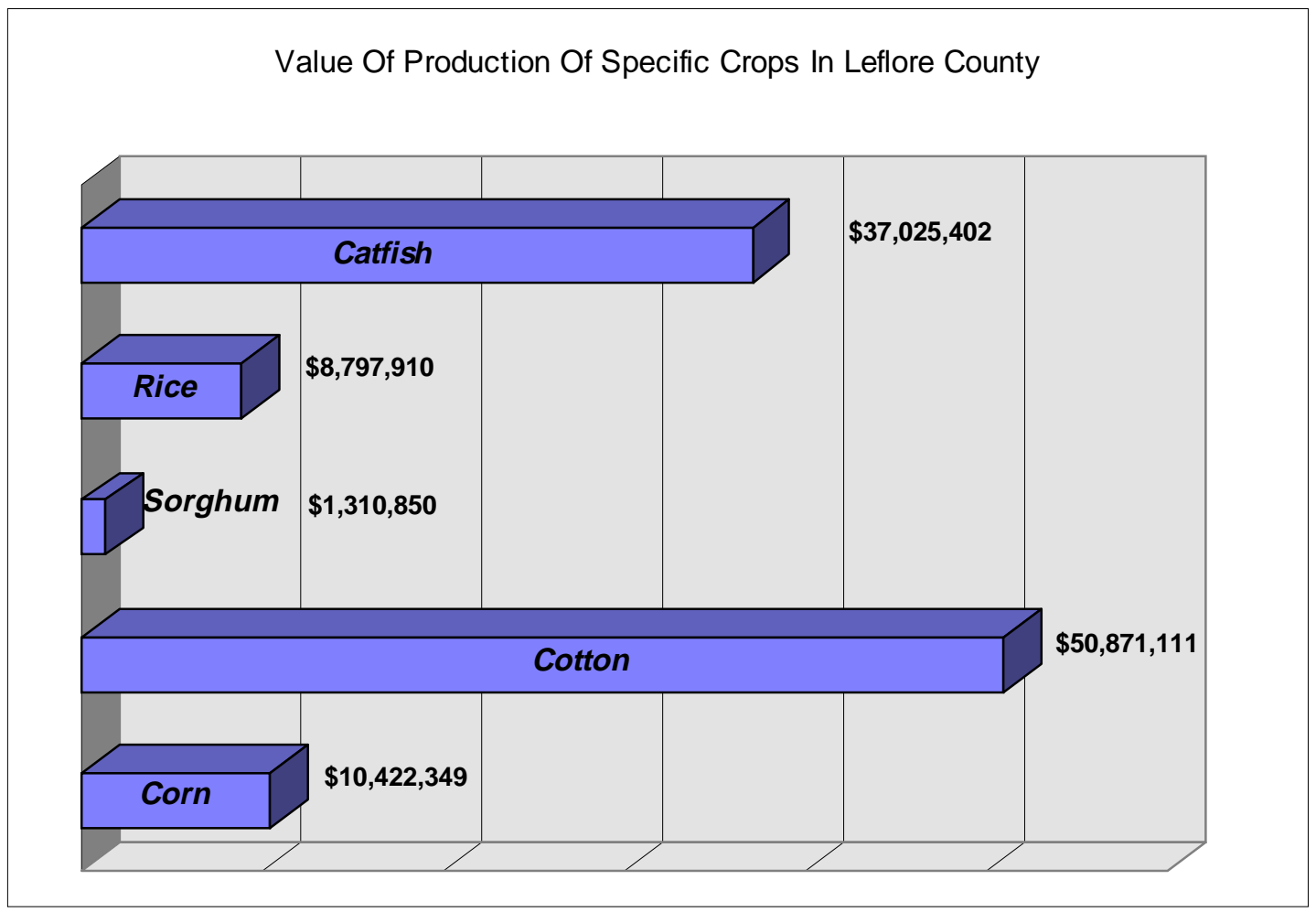

Figure 6

\begin{tabular}{l|rc}
\hline Production & State Production & County Ranking \\
\hline Cotton & $\$ 699,791,000$ & Fourth \\
Catfish & $275,000,000$ & Third \\
Corn & $209,814,000$ & Fourth \\
Rice & $124,800,000$ & Sixth \\
Sorghum & $15,372,000$ & Second \\
\hline
\end{tabular}

\section{$\underline{\text { Problem Statement }}$}

One of the greatest American accomplishments of in this century has been the building of an agricultural dynasty that is the envy of the world. The abundance of food 
and fiber proudly produced by less than two percent of our population supplies our country and provides agricultural commodity exports worldwide.

As generations of Americans grow more distant from their agrarian origins, fewer and fewer people understand agriculture's importance to society. Yet, increasingly, people with limited agricultural knowledge and background are determining agricultural policy. What the future holds for agriculture will determine the quality of life for all farmers, ranchers, suppliers, food processors, wholesalers, retailers, and consumers. Will tomorrow's leader be knowledgeable of the U.S. oldest industry? Are we preparing them to deal with the food and environmental issues that accompanies a consistently growing population? Will there be enough well-trained college graduates to fill the projected vacancies in agriculture careers? What are students' and teachers' perceptions of agriculture, and how do those perceptions impact the agriculture industry.

\section{Purpose of the Study}

The purpose of this study is to assess the perceptions of high school students and teachers in Leflore County, Mississippi, regarding agriculture and provide baseline data regarding the perceptions of agriculture by high school teachers and students residing in an agriculturally dependent county with no secondary agricultural education program. The study may provide information to school officials, policy makers, and USDA officials to assist them in their efforts in increasing agriculture literacy and diversity in the agricultural sector.

\section{Objectives of the Study}

1. To assess the perceptions of high school teachers and students regarding agriculture in Leflore County.

2. To compare the perceptions of teachers and students regarding agriculture.

3. To compare the perceptions of teachers by gender, ethnicity, place of residence, and school.

4. To compare the perceptions of students by gender, ethnicity, place of residence, and school.

5. To determine the influence of selected variables on the perceptions of teachers and students regarding agriculture. 


\section{Limitations of the Study}

This study is limited to the perceptions of high school seniors and their teachers in Leflore County, Mississippi. 
CHAPTER II

\section{LITERATURE REVIEW}

\section{General Public's Perception of Agriculture}

Historically the word agriculture has been used synonymously with the word farming. Agriculture is often associated with mental images of a farmer and his family planting and harvesting crops and ranching. The general public infrequently acknowledges the science, business, and marketing aspects of agriculture.

The United States agriculture industry leads the world in meeting the needs of a growing population with a reduced supply of resources. It is an industry that has become increasingly complex and technologically advanced, thus requiring a stable supply of well-trained and highly educated professionals to ensure its future success (Brown, 1994).

Globalization, interdependence, and competition in world agricultural markets have created a need for greater understanding of the marketing systems in the United States and the world. The business and industry sectors of agriculture, both on and off the farm, have become more technological, specialized, business-oriented, and efficient (McCracken \& Newcomb, 1981). Today's agribusiness environment consists of sophisticated customers beset with intense competition, razor thin profits, and rapidly changing production and business technologies. As a result of this change, new skills and programs will need to be developed to meet the emerging educational needs in agriculture - especially agribusiness (Radhakrishna and Bruening, 1992).

\section{$\underline{\text { Students' Perceptions of Agriculture }}$}

The agricultural sector tends to be perceived by high school youth and the general public as consisting solely of production and farming (Kirts, 1993). Agriculture and careers in agriculture have suffered from a negative image. In a study conducted by Mallory and Sommer (1986), high school students were unaware of the range of opportunities in agricultural careers. In some cases, students did not even know the meaning of the word agriculture.

Students perceive agricultural careers as being an underpaid, low prestige, male oriented occupation. Students perceive agricultural careers as boring and laborious work, which involves more muscle than brain. They view careers in agriculture as field work 
that involves more men than women. Individual perceptions need to be corrected and students need to be shown that careers in agriculture are numerous, diverse, well paid, stable, advanced in technology, and requiring advanced education (Leising, 1991).

Talbert and Larke (1993) determined that minority students were underrepresented in introductory agriscience courses, and identified African-American and Hispanic students as having more negative perceptions of agriculture than Caucasian students. Recruitment of non-traditional students is crucial to prepare them for a diverse and rapidly changing workplace, and to assure an adequate cadre of students in vocational programs such as agriculture (Sutphin, 1994). Gender and ethnicity differences in students' perceptions are also a current concern. Studies regarding ethnic differences have identified that Black and Hispanic students are more likely to have a negative perception of agriculture than students in other ethnic groups (Nichols and Nelson, 1993).

\section{Common Misconceptions Regarding Agriculture}

The number of agriculture programs and students has declined in recent years. Krueger and Riesenberg (1991) found that students often have misperceptions of the agricultural industry and agricultural careers. These misconceptions could lead to further enrollment decline unless corrected. It is essential that educators begin to understand current perceptions of students regarding agriculture.

There are at least two misconceptions that students held about careers in agriculture. The first misconception was that students with limited academic abilities can succeed in an agricultural occupation, and the second was that vocational agriculture is for someone else's child (Golloday, 1981).

Student misperceptions of the agricultural industry and agricultural career opportunities may negatively affect recruitment (Krueger \& Riesenberg, 1991). Many high school students, unaware of the range of agricultural jobs, rate them low in terms of stability, a secure future, and earning power (Mallory \& Sommer, 1986).

Students usually equate a career in agriculture with farming or ranching, rather than with the science or business aspects of agriculture. This can lead to a pervasively negative opinion of pursuing a career in agriculture. Students prefer careers that would supply a stable and secure future and the ability to increase their earning power (Orthel, 1989). 
Results from a study conducted by Krueger and Riesenberg (1991) indicated:

- Males enrolled in agriculture vocational education indicated an interest in aquaculture, farming, and environmental management.

- Males not enrolled in agriculture courses prefer careers in biology, bio-technology, and genetic engineering.

- Female agriculture students are interested in food science, plant science, applied economics, food safety, and community nutrition.

- Non-agriculture female students prefer applied economics, food safety, and community nutrition.

- Unlike the non-agricultural oriented male and females, both male and female agriculture students felt that agriculture careers paid.

- Male agriculture students agree that agriculture careers are creative, secure, and requires the use of special talents.

- Female students with an agriculture background agree that agriculture careers allow you to work with people and earn respect within the community.

\section{Guidance Counselors' Roles in Students Career Choices}

Historically, there has been agreement among those responsible for counselor education that school counselors should assume a central role in promoting career education programs in the schools. Counselors play a major role in the development of students from secondary education to the professional arena. To promote a central role in career education, counselors need to have a thorough understanding of the various kinds of careers and the changes characterizing the professional arena. In general, counselors may advise students to choose either conventional academic programs or vocational programs, each leading to dramatically different careers (Woodard \& Herren, et al., 1995).

\section{Importance of Agriculture Literacy}

Most Americans, regardless of age, have limited knowledge of agriculture and the agriculture industry. All Americans need to be agriculturally literate in order to make inform choices with references to policies and decisions that may affect the food and fiber 
industry. The public and private educational system are one of the most effective means of circulating knowledge in order to improve the image and knowledge of a particular discipline.

One consequence of the populace's lack of agricultural knowledge is the development of public policy that adversely affects the production of food and fiber. Many bad decisions affecting food production can be traced to a lack of understanding about agriculture on the part of the 98 percent of our people who do not live on farms. There are few issues of greater importance than an adequate supply of food, proper use of food, and an understanding of the industry that produces food. Other prominent researchers have called for all citizens to develop a minimum level of knowledge about the production of food, in order for reasoned decisions to be made about policies and issues that affect agriculture (Mawby, et al., 1984).

\section{The Role of Agriculture Education}

Agricultural education must begin at an early age and continue throughout life. "Food for America" and "Ag in the Classroom" are new programs that attempt to introduce agriculture related material to children nationwide. The lessons used in these programs are those that are typically used in areas that are agriculturally oriented. Very little is being done to educate adults, the current policymakers, about the agricultural industry.

If American agriculture is going to feed an ever-growing population, then it is crucial that all citizens are informed so they can make intelligent decisions concerning the production of food and fiber (Raven, 1994).

Vocational education in agriculture was developed as an integral part of public secondary school education therefore, contributed to the general objectives and philosophy of such education. Initially, the primary aim of education in agriculture was to train present and prospective farmers for proficiency in farming. Another goal of vocational education in agriculture has been to develop abilities within the individual to help him or her to solve their social and economic problems in order that they may become proficient in farming. The most concise objectives compiled by authorities in the field suggested that vocational education in agriculture be concerned with a pragmatic approach in developing abilities in the following areas: producing farm products 
efficiently, marketing farm products advantageously conserving natural resources, managing a farm business, and maintaining a favorable environment.

\section{Impact of Educational Reform}

During the last decade the educational reform movement has significantly impacted all aspects of education. New standards in education, a result of the Excellence in Education movement, require high school students to meet more stringent graduation and college vocational education, especially vocational education in agriculture. Many agricultural educators contend the new standards limit the options of students enrolled in high school agriculture programs, because these students may be enrolled in preparatory curriculums and also sustain their enrollment in secondary agriculture classes.

\section{Factors Influencing Students to Participate in Agriculture Programs}

Aspirations have been influenced by factors, which are beyond the control of the individuals making the choices. People within the limits set by their native endowments, respond to the social structure within which they live to form various behavioral patterns that collectively constitute their personalities (Ogunrinde, 1981).

It is important to understand initially the role of information processing as an underlying factor in the formation beliefs. Findlay and Rawls (1984) found that parents and college professors provided the most influence to students to major in an agricultural curriculum. Cooperative extension personnel, friends, high school counselors, 4-H leaders, university students, and high school teachers have been indicated as individual who influenced a student to major in an agriculture discipline.

The requirements imposed upon high school students in the 1980s reduced the number of students able to enroll in agricultural programs; thus fewer agricultural programs exist today to inform the public about the nature of agriculture in society today (Brown, 1994).

Carter and Leibold (1987) stated that universities need to share information about agricultural opportunities through literature and student ambassadors, and recruiters should be used to accentuate enrollment. Betts and Newcomb (1986) suggested working with science teachers in urban areas to provide them with interesting agricultural information that could be integrated into the curricula. 
Thompson and Russell (1993) emphasized the link between declining enrollment in agricultural education and a shortage of qualified individuals in the food and agricultural sciences. They recommended developing an understanding of student attitudes and beliefs about agricultural science to facilitate recruitment.

A student's decision to enroll in agricultural education programs is affected by interpersonal factors including interests, attitudes, and value systems; as well as perception of course content, pedagogical strategies, and career potential. Sociocultural factors, including gender and ethnicity, have also been shown to affect student attitudes, beliefs, and enrollment in agricultural courses are needed to facilitate recruitment, inform guidance counseling, and curriculum development (Newsom-Stewart \& Sutphin, 1994).

A factor identified as related to the students' perceptions of agricultural careers seemed to be secondary education in agriculture. Students who have had some background in high school agriculture seemed to be more interested in pursuing an agricultural career than were non-agricultural students.

Another factor identified as being related to the students' perceptions of agricultural careers was place of residence, and whether or not the students had ever lived on a farm. Students who had lived on a sizable acreage farm indicated a higher interest in agricultural careers.

Beliefs and attitudes held about an issue or an event are good predictions of intentions to participate in an educational program. Interpersonal reasons can be a potential barrier that influences students not to enroll in vocational education, and these include: attitudes, perceptions, images, motivation, career maturity, and value systems. Personal issues may also encourage enrollment in agriculture; similarly, a desire to enhance the quality of life (Birkenholz, Frick, Gardner, \& Machtmes, 1995).

\section{$\underline{\text { Summary of Related Literature }}$}

Agriculture is the very basis of civilization. American's traditions and cultures all comes from agriculture. The United States agriculture industry leads the world in meeting the needs of a growing population with a reduced supply of resources. The agriculture sector is so efficient that only two percent of the country's population is involved directly in the production agriculture but produces about 17 percent of the Gross National 
Product. Because a vast majority of the population is more than one generation removed from agriculture, most Americans know little about food and fiber production. One consequence of the populace's lack of agricultural knowledge is the development of public policy that adversely affects the production of food and fiber. The agriculture industry will continue to suffer from a negative image until all citizens develop a minimum level of knowledge about the agriculture. 


\section{CHAPTER III \\ PROCEDURES}

This study was conducted to provide baseline data regarding teachers and students' perceptions regarding agriculture in Leflore County, Mississippi. This study investigated several factors that may contribute to teachers' and students' perceptions of agriculture. $\underline{\text { Design }}$

The descriptive survey research method was used to collect data from high school teachers and students in Leflore County. Twelfth-grade classes at all three public high schools were surveyed independently.

Population and Sample

The sample for this study was teachers and senior students from the three high schools in Leflore County: Amanda Elzy, Leflore County, and Greenwood. Neither of the two school districts in Leflore County offer agriculture courses. All three area high schools were chosen because of the researcher's interest in the entire population of high school seniors in the two school districts. During the 1998-1999 academic school year, there were approximately 130 high school teachers and 430 high school seniors in the public and the private schools. A total of 188 students and 52 teachers comprised the sample for this study. The two county schools (Leflore County and Amanda Elzy) are smaller schools and mostly rural. Greenwood High School is the largest school in the county, and it is located within the city limits of Greenwood. Neither the County or public school districts had a secondary agricultural education curriculum.

Instrumentation

Two data collection instruments were developed based upon information gathered from related literature, which would provide data to meet the objectives of this study. The surveys were organized into two sections. Section I of the student's survey consisted of two parts; Part A was composed of statements which requested perceptions of students regarding agriculture on a four-point, Likert-type scale. The choices were: $1=$ strongly disagree, 2 = disagree, $3=$ agree, $4=$ strongly agree. Part $\mathrm{B}$ requested the student to write a short statement depicting his or her perception of agriculture. Section II consisted of questions pertaining to demographic characteristics. These characteristics included: 
gender, home location, ethnicity, and agriculture experience. The teacher's survey consisted of only Part A and Section II.

\section{Data Collection Procedures}

Data were collected using an instrument created by the researcher with the assistance of his graduate committee. The researcher personally administered the survey at each of the high schools.

\section{Analysis of Data}

This study sought to measure the perceptions of Leflore County high school students and teachers regarding agriculture. Data collected were analyzed using SPSS. Descriptive analyses were performed on the data. Analyses of variance, correlation, frequencies, and means were used to describe and analyze the data.

\section{Use of Findings}

Findings from this study may be used to provide information to school officials, policy makers, and USDA officials to assist them in their efforts in increasing agriculture literacy and diversity in the agricultural sector. 


\section{CHAPTER IV}

\section{FINDINGS}

The purpose of this study was to assess the perceptions of high school teachers and students in Leflore County, Mississippi regarding agriculture and provide baseline data regarding the perceptions of agriculture high school students and teachers residing in an agriculturally dependent county with no agricultural education program. To accomplish this purpose, a sample of 240 high school teachers and students were surveyed for their perceptions regarding agriculture.

\section{Objectives of the Study}

1. To assess the perceptions of high school teachers and students regarding agriculture in Leflore County.

2. To compare the perceptions of teachers and students regarding agriculture.

3. To compare the perceptions of teachers by gender, ethnicity, place of residence, and school.

4. To compare the perceptions of students by gender, ethnicity, place of residence, and school.

6. To determine the influence of selected variables on the perceptions of teachers and students regarding agriculture.

Responses of Leflore County high school student and teachers are summarized in the following pages. Results of the data analyses are presented in the following areas: description of the respondents; demographics; mean responses for individual perception statements; comparison of perceptions among groups and by various independent factors.

Data obtained were analyzed at West Virginia University using the Statistical Package for Social Sciences for Windows (SPSS). Levels of significance were set a priori at $\mathrm{p}<0.05$ for all statistical tests. Means and standard deviations were determined for each statement.

Instrument Reliability

Reliability means dependability, or trustworthiness. Basically, it is the degree to which a test consistently measures whatever it measures (Gay, 1996). The Cronbach alpha, or coefficient alpha, is widely used to measure the reliability of educational 
research instruments. A reliability score of 1.00 is an indication of a perfectly reliable instrument. In the reliability analysis conducted on the instrument used in this study, alpha equals 0.8478 .

Statement 27 was deleted from the pool of individual perception statements before data analysis because the statement occurred twice on the instruments. The researcher believed that the students responded to the statement more accurately the first time that the statement occurred. The researcher did not believe that the question contributed to the overall meaning of the study, so the statement was omitted from data analysis.

\section{Description of the Respondents}

Each respondent completing the instrument was provided the opportunity to indicate his/her gender, race, place of residence, and school attended. In the demographic section of the instrument, the students were asked to indicate their favorite subjects and the teachers were asked to indicate the subjects that they taught. In addition, the respondents were asked to indicated whether or not they had done agriculture related work and if they had relatives who had done agriculture related work.

\section{$\underline{\text { Sample Size }}$}

All three public high schools in Leflore County were represented in this study. The population consisted of 240 participants, 188 students and 52 teachers. Females represented $65 \%$ of the population. Five participants did not respond to the gender question. Greenwood High School made up more than half of the entire population $(\underline{\mathrm{n}}=52.5 \%)$ and Leflore County $(\underline{\mathrm{n}}=19.6 \%)$ and Elzy $(\underline{\mathrm{n}}=27.9 \%)$ made up the remaining portion of the population. Greenwood High School had the most teachers to respond $(\underline{n}=25)$, followed by Elzy $(\underline{n}=22)$, and Leflore County $(\underline{n}=5)$.

\section{Participants' Place of Residence}

In the demographic section of the survey, the participants were asked to indicate whether or not they lived in a city, town, or on a farm. A total of 235 out of 240 participants responded to this question. Over $63.8 \%$ of the population resided in the city, while only $2.9 \%$ live on a farm. Five participants did not respond to this question. Descriptive statistics of the respondents by place of residence are presented in Table 1. 
Table 1.

$\underline{\text { Residence of the Participants }}$

\begin{tabular}{lrr}
\hline Residence & Frequency & Percent \\
\hline City & 153 & 63.8 \\
Town & 75 & 31.3 \\
Farm & 7 & 2.9 \\
System Missing & 5 & 2.1 \\
Total & 240 & 100.0 \\
\hline
\end{tabular}

\section{Experience in Agricultural related Work}

As illustrated in Table 2, respondents were asked to indicate whether or not he/she had done agricultural related work. More than half (55.8\%) of the participants indicated that they had done agricultural related work, while $42.1 \%$ indicated that they had not. Only two options were provided for this particular question: Yes and No. Five participants did not respond to this question.

Table 2.

Agricultural Related Work

\begin{tabular}{lrc}
\hline Response & Frequency & Percent \\
\hline Yes & 134 & 55.8 \\
No & 101 & 42.1 \\
System Missing & 5 & 2.1 \\
Total & 240 & 100.0 \\
\hline
\end{tabular}

\section{$\underline{\text { Relatives' Experience in Agricultural related Careers }}$}

The data in Table 5 depicts the experience of the respondents' relatives in agricultural related work. Over $49 \%$ of the respondents indicated that they had relatives that had been involved in agricultural related work. $47.5 \%$ of the population reported that they did not have relatives that were employed by the agriculture industry. Two options were provided for this particular question: yes and no. Eight participants did not respond to this question. 
Table 3.

$\underline{\text { Relative with Agricultural Related Experience }}$

\begin{tabular}{lcc}
\hline Response & Frequency & Percent \\
\hline Yes & 118 & 49.2 \\
No & 114 & 47.5 \\
System Missing & 8 & 3.3 \\
Total & 240 & 100.0 \\
\hline
\end{tabular}

\section{Participants' Ethnicity}

Illustrated in Table 4 is a description of the participants' response to the ethnicity question presented in the demographic section of the survey. The respondents were asked to select which ethnic group he/she belongs. The following options were given: AfricanAmerican, Asian-American, Hispanic-American, Native American, White American, and other. Ninety-two percent of the students and 51.9\% of the teachers indicated that they were African Americans. Six students and 2 teachers did not respond to this question. Table 4.

Participants Ethnic Background

\begin{tabular}{lrccc}
\hline & \multicolumn{2}{c}{ Student } & \multicolumn{2}{c}{ Teacher } \\
Ethnicity & Frequency & Percent & Frequency & Percent \\
\hline African American & 173 & 92.0 & 27 & 51.9 \\
Other & 9 & 4.8 & 23 & 44.2 \\
System Missing & 6 & 3.2 & 2 & 3.8 \\
Total & 188 & 100.0 & 52 & 100.0 \\
\hline
\end{tabular}

\section{Mean Responses for Individual Perception Statements}

Participants were asked to rate their perceptions of various statements regarding agriculture. Respondents rated the statements on a scale of one to four ( $1=$ Strongly Disagree; 2 = Disagree; 3 = Agree; $4=$ Strongly Agree). The teachers and students indicated the highest ratings for: "Agriculture careers are for both men and women," (M=3.23), "More people should appreciate the agricultural industry," $(M=3.14)$, and 
"Agriculture careers pay well," $(M=2.93)$. The respondents indicated the lowest ratings for "Agriculture careers are mostly for women" (M=1.71), "Agriculture is for people that live in rural areas," (M=2.08), and "Agriculture careers are mostly for men," (M=2.08). A complete list of means and standard deviations of statements regarding perceptions of agriculture can be found in Table 5 . 
Table 5 .

$\underline{\text { Means and Standard Deviations for Individual Perceptions }(\mathrm{N}=240)}$

\begin{tabular}{lccr}
\hline Statements & $\underline{\mathrm{n}}$ & Mean & $\underline{\mathrm{SD}}$ \\
\hline Agriculture careers are for both men and women. & 235 & 3.23 & .85 \\
More people should appreciate the agricultural industry. & 233 & 3.14 & .74 \\
Agriculture careers pay well. & 232 & 2.93 & .79 \\
Agriculture is essentially farming. & 236 & 2.89 & .82 \\
Agriculture classes should be offered in my school. & 236 & 2.83 & .78 \\
A course in agriculture would be valuable to all students. & 237 & 2.78 & .90 \\
There is not enough emphasis placed on agriculture in my school. & 235 & 2.77 & .92 \\
A course in agriculture would have helped me to develop skills & & & \\
needed for employment in business and industry. & 236 & 2.73 & .81 \\
I would have benefited from a course in agriculture. & 234 & 2.72 & .87 \\
I have a favorable perception of people in agriculture careers. & 233 & 2.72 & .89 \\
I should be knowledgeable of the agricultural industry. & 239 & 2.70 & .77 \\
Agriculture classes in our school would benefit & & & \\
college prep students. & 237 & 2.69 & .82 \\
I take pride in learning about the agriculture industry. & 232 & 2.63 & .79 \\
Careers in agriculture are abundant. & 236 & 2.61 & .73 \\
All students should be required to take a basic agricultural course. & 235 & 2.59 & .83 \\
Agriculture classes would provide me with competencies & & & \\
I would need to succeed in college. & 237 & 2.59 & .83 \\
I am familiar with career opportunities available in agriculture. & 232 & 2.59 & 2.18 \\
I have a favorable perception of agriculture careers. & 236 & 2.54 & .86 \\
My family history influenced my perception regarding agriculture. & 233 & 2.48 & .96 \\
My personal experiences influenced my perception of agriculture. & 232 & 2.40 & .96 \\
The media influenced my perception of agriculture. & 232 & 2.30 & .86 \\
I have participated in an agriculture club (e.g., 4-H, FFA). & 236 & 2.16 & 1.05 \\
Agriculture classes are primarily intended for the & 237 & 2.09 & .86 \\
non-college bound student. & 234 & 2.08 & .99 \\
Agriculture careers are mostly for men. & 234 & 2.08 & .94 \\
Agriculture is for people that live in rural areas. & 240 & 1.71 & .82 \\
Agriculture careers are mostly for women. & & & \\
\hline Note. Scale Values: & & & \\
\hline
\end{tabular}

Note. Scale Values: 1 = Strongly Disagree; 2 = Disagree; 3 = Agree; 4 = Strongly Agree. $* \mathrm{p}<0.05$ 


\section{Comparison of Perceptions Between Teachers and Students}

An ANOVA was generated to affirm whether or not a significant statistical difference existed between the mean scores between the two groups. An ANOVA value less than .05 indicates that a significant statistical difference exists between the mean scores of the groups. A practical difference alludes to a situation where there is a statistical difference and a meaningful difference in the way two groups viewed a particular statement. The parameters used to determine if a practical difference existed between groups for individual perception statements were: strongly disagree (1.0-1.49), disagree (1.5-2.49), agree (2.5-3.49); strongly disagree (3.5-4.0).

Shown in Table 6 are comparisons of mean scores of teachers and students for questions 1-28 of the research instruments. The teachers viewed all but one of the statements significantly higher than did the students. For ten of the individual perception statements there were significant statistical differences, but no practical differences.

In this comparison, teachers agreed and students disagreed with the following statements:

"I have a favorable perception of agriculture careers," (teachers 2.35 vs. students 3.22). "My personal experiences influenced my perception of agriculture," (teachers 2.24 vs. students 3.00). "I have participated in an agriculture club," (teachers 2.03 vs. students 2.67). "My family history influenced my perception regarding agriculture," (teachers 2.33 vs. students 3.00). "I am familiar with career opportunities available in agriculture," (teachers 2.41 vs. students 3.25).

"Agriculture careers are for both men and women. Teachers (M 3.58) strongly agreed, whereas students $(M=3.14)$ only agreed. The respondents rated this statement higher than they did any of the other individual perception statements.

The students scored only one of the individual perception statements, where a significant difference was found, higher than did the teachers, but there was no practical difference in the way students and teachers viewed the following statement. "Agriculture careers are for mostly women" (teachers 1.77 vs. students 1.50). Both teachers and disagreed with the statement. 
Table 6.

$\underline{\text { Teachers and Students Ratings for Individual Perception Statements }}$

\begin{tabular}{|c|c|c|c|c|}
\hline \multirow[b]{2}{*}{ Statement } & \multicolumn{4}{|c|}{ Means } \\
\hline & $\begin{array}{c}\text { Grand } \\
(\underline{N}=236)\end{array}$ & $\begin{array}{l}\text { Student } \\
(\underline{\mathrm{n}}=185)\end{array}$ & $\begin{array}{l}\text { Teacher } \\
(\underline{n}=51)\end{array}$ & $\begin{array}{c}\text { F- } \\
\text { Value }\end{array}$ \\
\hline $\begin{array}{l}\text { Agriculture careers are for both men and } \\
\text { women. }\end{array}$ & 3.23 & 3.14 & 3.58 & $10.90 *$ \\
\hline $\begin{array}{l}\text { More people should appreciate the agricultural } \\
\text { industry. }\end{array}$ & 3.14 & 3.04 & 3.49 & $14.85^{*}$ \\
\hline $\begin{array}{l}\text { A course in agriculture would be valuable to } \\
\text { all students. }\end{array}$ & 2.78 & 2.68 & 3.13 & $11.00 *$ \\
\hline $\begin{array}{l}\text { There is not enough emphasis placed on } \\
\text { agriculture in my school. }\end{array}$ & 2.77 & 2.70 & 3.00 & $4.32 *$ \\
\hline $\begin{array}{l}\text { A course in agriculture would have helped me } \\
\text { to develop skills needed for employment in } \\
\text { business and industry. }\end{array}$ & 2.73 & 2.65 & 3.02 & $8.40 *$ \\
\hline $\begin{array}{l}\text { I have a favorable perception of people in } \\
\text { agriculture careers. }\end{array}$ & 2.72 & 2.58 & 3.19 & $20.80 *$ \\
\hline $\begin{array}{l}\text { I would have benefited from a course in } \\
\text { agriculture. }\end{array}$ & 2.72 & 2.56 & 3.27 & $29.82 *$ \\
\hline $\begin{array}{l}\text { I should be knowledgeable of the agricultural } \\
\text { industry. }\end{array}$ & 2.70 & 2.59 & 3.10 & $18.50 *$ \\
\hline $\begin{array}{l}\text { Agriculture classes in our school would benefit } \\
\text { college prep students. }\end{array}$ & 2.69 & 2.59 & 3.06 & $14.02 *$ \\
\hline $\begin{array}{l}\text { I take pride in learning about the agriculture } \\
\text { industry. }\end{array}$ & 2.63 & 2.51 & 3.10 & $23.71 *$ \\
\hline $\begin{array}{l}\text { I am familiar with career opportunities } \\
\text { available in agriculture. }\end{array}$ & 2.59 & 2.41 & 3.25 & $5.73 *$ \\
\hline $\begin{array}{l}\text { Agriculture classes would provide me with } \\
\text { competencies I would need to succeed in } \\
\text { college. }\end{array}$ & 2.59 & 2.53 & 2.79 & $4.02 *$ \\
\hline $\begin{array}{l}\text { I have a favorable perception of agriculture } \\
\text { careers. }\end{array}$ & 2.54 & 2.35 & 3.22 & $48.95^{*}$ \\
\hline $\begin{array}{l}\text { My family history influenced my perception } \\
\text { regarding agriculture. }\end{array}$ & 2.48 & 2.33 & 3.00 & $20.50 *$ \\
\hline $\begin{array}{l}\text { My personal experiences influenced my } \\
\text { perception of agriculture. }\end{array}$ & 2.40 & 2.24 & 3.00 & $27.57 *$ \\
\hline $\begin{array}{l}\text { I have participated in an agriculture club (e.g., } \\
\text { 4-H, FFA). }\end{array}$ & 2.16 & 2.03 & 2.67 & $15.18^{*}$ \\
\hline Agriculture careers are mostly for women. & 1.71 & 1.77 & 1.50 & $4.57 *$ \\
\hline
\end{tabular}




\section{Comparison of Perceptions by Gender}

Presented in Table 7 are comparisons of mean scores of male and female participants. There were significant differences in the way males and females viewed these four individual perception statements. The males agreed with each of the statements, while females disagreed with all but one of the statements:

"My personal experiences influenced my perception of agriculture," (males 2.58 vs. females 2.30). "My family history influenced my perception regarding agriculture," (males 2.66 vs. females 2.36). "Agriculture classes would provide students with the competencies they need to succeed in college," (males 2.90 vs. females 2.43).

“Agriculture classes would provide me with competencies I would need to succeed in college," is the only statement, out of four, that both males and females agreed with.

Table 7.

\section{Perceptions of Students and Teachers by Gender}

\section{Mean}

Statement Grand Male Female F-Value $(\underline{N}=229) \quad(\underline{n}=78) \quad(\underline{n}=151)$

\begin{tabular}{lllll}
\hline I would have benefited from a course in agriculture. & 2.70 & 2.90 & 2.60 & $6.06^{*}$
\end{tabular}
Agriculture classes would provide me with competencies I would need to succeed in college. $\quad \begin{array}{llll}2.59 & 2.90 & 2.43 & 17.29 *\end{array}$ My family history influenced my perception regarding agriculture. $2.46 \quad 2.66 \quad 2.36 \quad 5.20^{*}$ My personal experiences influenced my perception of $\begin{array}{lllll}\text { agriculture. } & 2.40 & 2.58 & 2.30 & 4.18^{*}\end{array}$

Note. Scale Values: 1 = Strongly Disagree; 2 = Disagree; 3 = Agree; 4 = Strongly Agree. $* \mathrm{p}<0.05$ 


\section{Comparison of Perceptions of Students and Teachers by Schools}

Data presented in Table 8 depicts the individual perception statements in which there were significant differences between perceptions of teachers and students by schools. Participants in Elzy High School rated five of the seven statements significantly higher than did those in other schools, whereas teachers and students in Leflore County High School rated five of the seven statements lower than those in other schools.

Practical differences were found in only two of the individual perception statements. They were "Agriculture careers are for both men and women" and "Careers in agriculture are abundant." In both cases, participants in Elzy High School rated the statements highest and respondents in Leflore County High School rated them the lowest. Participants in Elzy High School strongly agreed that "Agriculture careers are for both men and women," whereas participants in other schools only agreed. Also, participants in Elzy High School agreed that "Careers in agriculture are abundant," whereas those in other high schools disagreed. 
Table 8.

$\underline{\text { Perceptions of Teachers and Students by Schools }}$

\begin{tabular}{|c|c|c|c|c|c|}
\hline \multirow[b]{2}{*}{ Statement } & \multicolumn{5}{|c|}{ Mean } \\
\hline & $\begin{array}{c}\text { Grand } \\
(\underline{N}=236)\end{array}$ & $\begin{array}{c}\text { Elzy } \\
(\underline{n}=66)\end{array}$ & $\begin{array}{l}\text { Leflore } \\
(\underline{n}=47)\end{array}$ & $\begin{array}{l}\text { Greenwood } \\
(\underline{\mathrm{n}}=123)\end{array}$ & F-Value \\
\hline $\begin{array}{l}\text { Agriculture careers are for both men and } \\
\text { women. }\end{array}$ & 3.23 & 3.55 & 3.09 & 3.12 & $6.44 *$ \\
\hline $\begin{array}{l}\text { I have a favorable perception of people in } \\
\text { agriculture careers. }\end{array}$ & 2.72 & 2.54 & 2.55 & 2.88 & $4.16^{*}$ \\
\hline $\begin{array}{l}\text { I would have benefited from a course in } \\
\text { agriculture. }\end{array}$ & 2.72 & 2.94 & 2.57 & 2.66 & $3.20 *$ \\
\hline $\begin{array}{l}\text { Agriculture classes in our school would } \\
\text { benefit college prep students. }\end{array}$ & 2.69 & 2.89 & 2.55 & 2.63 & $3.09 *$ \\
\hline Careers in agriculture are abundant. & 2.61 & 2.79 & 2.32 & 2.63 & $5.96^{*}$ \\
\hline $\begin{array}{l}\text { I have participated in an agriculture club } \\
\text { (e.g., 4-H, FFA). }\end{array}$ & 2.16 & 2.42 & 2.11 & 2.03 & $3.06 *$ \\
\hline $\begin{array}{l}\text { Agriculture is for people that live in rural } \\
\text { areas. }\end{array}$ & 2.08 & 2.00 & 1.83 & 2.22 & $3.22 *$ \\
\hline
\end{tabular}

Note. Scale Values: 1 = Strongly Disagree; $2=$ Disagree; $3=$ Agree; $4=$ Strongly Agree.

$* \mathrm{p}<0.05$

\section{Comparison of Perceptions Between Students, by Schools}

Students in Greenwood High School rated three of the two statements that were found to be statistically different, higher than did the students in other schools. "Careers in agriculture are abundant," students in Elzy High School and Greenwood High School agreed with this statement, whereas students in Leflore County disagreed. "I have a favorable perception of people in agriculture careers," students in Greenwood High School agreed with this statement, whereas the students at the other schools disagreed. Details of the comparison of students' perceptions by schools are outlined in Table 9. 
Table 9.

Comparison of Perceptions among Students by Schools

$\underline{\text { Mean }}$

Statement Grand Elzy Leflore Greenwood F-Value

$(\underline{\mathrm{N}}=185) \quad(\underline{\mathrm{n}}=44) \quad(\underline{\mathrm{n}}=42) \quad(\underline{\mathrm{n}}=99)$

\begin{tabular}{llllll}
\hline Careers in agriculture are abundant. & 2.61 & 2.70 & 2.33 & 2.69 & $4.25^{*}$
\end{tabular}

I have a favorable perception of people

$\begin{array}{llllll}\text { in agriculture careers. } & 2.58 & 2.30 & 2.45 & 2.76 & 4.70 *\end{array}$

$\begin{array}{llllll}\text { Agriculture careers are boring. } & 2.29 & 2.36 & 1.98 & 2.40 & 2.96^{*}\end{array}$

Note. Scale Values: 1 = Strongly Disagree; 2 = Disagree; 3 = Agree; 4 = Strongly Agree. $* \mathrm{p}<0.05$

\section{Comparison of Perceptions Between Students by Gender}

Males agreed with five out of twelve individual perception statements in which significant statistical differences were found, whereas females only agreed with one out of twelve statements. Males scored each of the statements significantly higher than did females. "I should be knowledgeable of the agricultural industry," is the only statement in which males and females both agreed, whereas they both disagreed with seven of twelve statements. The four statements in which practical differences were found are as follows: "I would have benefited from a course I agriculture," (males 2.79 vs. females 2.42); “Agriculture classes would provide me with competencies I would need to succeed in college," (males 2.91 vs. females 2.42); "I have a favorable perception of agriculture careers," (males 2.52 vs. females 2.26); and "My family history influenced my perception regarding agriculture,” (males 2.58 vs. females 2.18). Detail of students' perceptions by gender is outlined in Table 10. 
Table 10.

Comparison of Perceptions among Students for Individual Statements

Statement

$$
\text { Mean }
$$

Grand Male Female F-Value

$(\underline{\mathrm{N}}=181)(\underline{\mathrm{n}}=58)(\underline{\mathrm{n}}=123)$

I should be knowledgeable of the agricultural industry.

$\begin{array}{llll}2.58 & 2.76 & 2.50 & 4.59 *\end{array}$

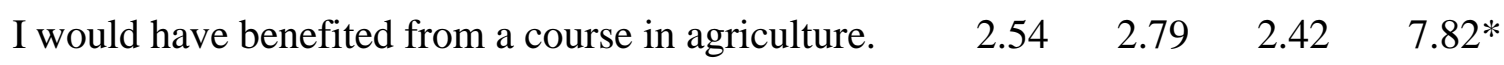

Agriculture classes would provide me with

competencies I would need to succeed in college.

$2.53 \quad 2.91 \quad 2.35 \quad 19.51 *$

I have a favorable perception of agriculture careers.

$2.34 \quad 2.52 \quad 2.26 \quad 4.39 *$

My family history influenced my perception regarding

agriculture.

$2.31 \quad 2.58 \quad 2.18 \quad 7.27 *$

My personal experiences influenced my perception of agriculture.

$2.23 \quad 2.43 \quad 2.13 \quad 4.76^{*}$

The agriculture industry interests me.

$2.24 \quad 2.48$

$2.135 .68 *$

Agriculture careers require more muscle than brain.

$2.23 \quad 2.49$

2.11

$6.86^{*}$

My family stresses the importance of agriculture.

$\begin{array}{llll}2.16 & 2.45 \quad 2.02 \quad 8.35 *\end{array}$

I may study agriculture after high school.

$\begin{array}{llll}2.16 & 2.43 \quad 2.03 \quad 7.92 *\end{array}$

I am considering a career in agriculture.

$2.14 \quad 2.44 \quad 2.00 \quad 9.09 *$

My friends have expressed interest in agriculture.

$2.08 \quad 2.34 \quad 1.96 \quad 7.55^{*}$

Note. Scale Values: 1 = Strongly Disagree; 2 = Disagree; 3 = Agree; 4 = Strongly Agree. $* \mathrm{p}<0.05$

\section{Comparison of Perceptions Between Teachers by Schools}

Presented in Table 13 is the comparison of teachers' mean scores for individual mean scores. Teachers in Elzy High School scored four out of five statements, where significant statistical differences were found, higher than did the teachers in other schools, whereas teachers in Leflore County High Schools scored three out of five statements lower than did other teachers. "Agriculture careers are for both men and women," teachers in Leflore County High School agreed with this statement, whereas the teachers from the other 
schools strongly agreed. "I have participated in an agriculture club," teachers in Greenwood High School disagreed with this statement, whereas the teachers at the other schools agreed. "Careers in agriculture are abundant," teachers in Elzy High School agreed with this statement, whereas teachers from the other schools disagreed. The data for perceptions between teachers by schools for the individual perception statements are outlined in Table 11.

Table 11.

Comparison of Teachers' Perceptions by Schools

\section{Mean}

Statement Grand Elzy Leflore Greenwood F-Value $(\underline{N}=51) \quad(\underline{n}=22) \quad(\underline{n}=5) \quad(\underline{n}=24)$

Agriculture careers are for both men and women. $3.58 \quad 3.82 \quad 2.80$ 3.52 $7.43 *$

Agriculture careers pay well.

I have participated in an agriculture club

2.84

3.18

2.80

2.54

$4.04^{*}$

Agriculture classes are primarily intended for the non-college bound student.

2.67

2.63 3.27 2.75 2.05 $6.91 *$ (e.g., 4-H, FFA).

Careers in agriculture are abundant.
Note. Scale Values: 1 = Strongly Disagree; 2 = Disagree; $3=$ Agree; 4 = Strongly Agree. $* \mathrm{p}<0.05$

\section{Comparison of Perceptions Between Teachers by Gender}

"All students should be required to take a basic agriculture class," The male teachers scored this statement significantly lower than did female teachers. Result of the comparison of perceptions between teachers for individual perception statements, in which a significant statistical difference was found, is presented in Table 12. 
Table 12.

Perceptions among Teachers by Gender

\begin{tabular}{|c|c|c|c|c|}
\hline \multirow[b]{2}{*}{ Statement } & \multicolumn{4}{|c|}{$\underline{\text { Mean }}$} \\
\hline & $\begin{array}{c}\text { Grand } \\
(\underline{\mathrm{N}}=181)\end{array}$ & $\begin{array}{l}\text { Male } \\
(\underline{n}=58)\end{array}$ & $\begin{array}{l}\text { Female } \\
(\underline{n}=123)\end{array}$ & F-Value \\
\hline \multicolumn{5}{|c|}{ All students should be required to take a basic } \\
\hline agricultural course. & 2.76 & 2.45 & 2.97 & $4.53 *$ \\
\hline
\end{tabular}

Note. Scale Values: 1 = Strongly Disagree; 2 = Disagree; 3 = Agree; 4 = Strongly Agree. $* \mathrm{p}<0.05$

\section{Comparison of Perceptions Among Students Who Had and Had Not Done Agriculture}

\section{$\underline{\text { Related Work }}$}

Individual perception statements where significant statistical differences were found, students who had done agricultural related work rated the statements higher than did those who had not done agricultural related work. "I should be knowledgeable of the agriculture industry," students who had done agricultural related work rated this statement significantly higher than did the other students. 
Table 13.

Perceptions of Students Who Had and Had Not Done Agriculture Related Work

\begin{tabular}{|c|c|c|c|c|}
\hline \multirow[b]{2}{*}{ Statement } & \multicolumn{4}{|c|}{$\underline{\text { Mean }}$} \\
\hline & $\begin{array}{l}\text { Grand } \\
(\underline{N}=182)\end{array}$ & $\begin{array}{c}\text { Yes } \\
(\underline{n}=99)\end{array}$ & $\begin{array}{c}\text { No } \\
(\underline{n}=83)\end{array}$ & F-Value \\
\hline More people should appreciate the agricultural industry. & 3.04 & 3.14 & 2.91 & $4.22 *$ \\
\hline Agriculture careers pay well. & 2.94 & 3.05 & 2.81 & $4.08 *$ \\
\hline \multicolumn{5}{|l|}{ There is not enough emphasis placed on agriculture in } \\
\hline my school. & 2.70 & 2.85 & 2.53 & $5.66^{*}$ \\
\hline I should be knowledgeable of the agricultural industry. & 2.59 & 2.75 & 2.41 & $9.39 *$ \\
\hline \multicolumn{5}{|l|}{ My personal experiences influenced my perception of } \\
\hline agriculture. & 2.24 & 2.41 & 2.04 & $8.29 *$ \\
\hline Agriculture careers are for mostly women. & 1.77 & 1.57 & 2.01 & $13.20 *$ \\
\hline
\end{tabular}

Note. Scale Values: 1 = Strongly Disagree; 2 = Disagree; 3 = Agree; 4 = Strongly Agree. $* \mathrm{p}<0.05$

Comparison of Perceptions Among Teachers Who Had and Had Not Done Agriculture Related Work

Outlined in Table 14 are comparisons of mean scores for teachers who had and had not done agricultural related work. "My family history influenced my perception regarding agriculture," teachers who had done agricultural related work scored this statement higher than did the other teachers.

Table 14.

Perceptions of Teachers Who had and had not Done Agriculture Related Work

\begin{tabular}{lccccc}
\hline Statement & \multicolumn{5}{c}{$\underline{\text { Mean }}$} \\
& $\begin{array}{c}\text { Grand } \\
(\underline{N}=50)\end{array}$ & $\begin{array}{c}\text { Yes } \\
(\underline{\mathrm{n}}=34)\end{array}$ & $\begin{array}{c}\text { No } \\
(\underline{\mathrm{n}}=16)\end{array}$ & F-Value \\
\hline $\begin{array}{l}\text { My family history influenced my perception regarding } \\
\text { agriculture. }\end{array}$ & 3.00 & 3.18 & 2.63 & $4.58^{*}$ \\
\hline
\end{tabular}

Note. Scale Values: 1 = Strongly Disagree; 2 = Disagree; 3 = Agree; 4 = Strongly Agree. $* \mathrm{p}<0.05$ 
Comparison of Perceptions Among Students That Have and Did Not Have Relatives Who Had Done Agricultural related Work

Presented in Table 15 are comparisons of mean scores of students who had or did not have relatives who had done agricultural work. In the statements where significant statistical differences were found, students that had relatives who had done agricultural related work scored each of the statements higher than did the other students. "I have a favorable perception of people in agriculture careers," students that had relatives who had done agricultural related work agreed with this statement, whereas the other students disagreed.

Table 15.

Comparison of Perceptions Among Students That Have and Did Not Have

Relatives Who Had Done Agricultural related Work

\begin{tabular}{|c|c|c|c|c|}
\hline \multirow[b]{2}{*}{ Statement } & \multicolumn{4}{|c|}{$\underline{\text { Mean }}$} \\
\hline & $\begin{array}{l}\text { Grand } \\
(\underline{\mathrm{N}}=176)\end{array}$ & $\begin{array}{c}\text { Yes } \\
(\underline{\mathrm{n}}=86)\end{array}$ & $\begin{array}{c}\text { No } \\
(\underline{\mathrm{n}}=90)\end{array}$ & F-Value \\
\hline More people should appreciate the agricultural industry. & 3.03 & 3.16 & 2.91 & $5.10^{*}$ \\
\hline \multicolumn{5}{|l|}{ There is not enough emphasis placed on agriculture in my } \\
\hline school. & 2.69 & 2.87 & 2.53 & $6.03 *$ \\
\hline \multicolumn{5}{|l|}{ I have a favorable perception of people in agriculture } \\
\hline careers. & 2.57 & 2.71 & 2.43 & $4.15^{*}$ \\
\hline \multicolumn{5}{|l|}{ My personal experiences influenced my perception of } \\
\hline agriculture. & 2.24 & 2.39 & 2.10 & $4.94 *$ \\
\hline Agriculture is for people that live in rural areas. & 2.06 & 2.22 & 1.90 & $4.94^{*}$ \\
\hline
\end{tabular}

Note. Scale Values: 1 = Strongly Disagree; $2=$ Disagree; $3=$ Agree; 4 = Strongly Agree. $\mathrm{p}<0.05$ 
Comparison of Perceptions Among Teachers That Have and Did Not Have Relatives Who Had Done Agricultural related Work

Statements where significant statistical differences were found, teachers that had relatives who had done agricultural related work scored each of the statements higher than did the other teachers. "More people should appreciate the agriculture industry," teachers that had relatives that had done agricultural related work strongly agreed with this statement, whereas the other teachers only agreed. "I have participated in an agriculture club," teachers who had relatives who had done some agricultural related work agreed with the statement, whereas the other teachers disagreed. Listed in Table 16 is a comparison of mean scores of teachers that had relatives who had done some agricultural related work.

Table 16.

Perceptions of Teachers That Have and Did Not Have Relatives Who Had Done Agricultural related Work

\section{$\underline{\text { Mean }}$}

Statement

Grand Yes No F-Value

$(\underline{N}=50) \quad(\underline{n}=30) \quad(\underline{n}=20)$

More people should appreciate the agricultural industry.

$4.50 *$

I have a favorable perception of agriculture careers.

2.90

$5.80 *$

I take pride in learning about the agriculture industry.

3.10

3.38

2.70

$17.08^{*}$

A course in agriculture would help students to

develop skills needed for employment in business and industry.

3.02

I have participated in an agriculture club (e.g., 4-H, FFA).

Note. Scale Values: 1 = Strongly Disagree; $2=$ Disagree; 3 = Agree; 4 = Strongly Agree. $* \mathrm{p}<0.05$ 


\section{Comparison of Perceptions of Teachers by Ethnicity}

Statements in which significant statistical differences were found, African American teachers scored four of five statements higher than the other teachers. "Careers in agriculture are abundant," African American teachers agreed with the statement, whereas other teachers disagreed. "Agriculture is for people that live in rural areas," African Americans teachers rated this statement lower than did other teachers. "Agriculture careers are for both men and women," African Americans scored this statement significantly higher than teachers did of ethnic groups. Data in Table 17 depicts the mean scores of teachers by ethnicity for individual perception statements.

Table 17.

Perceptions of Teachers by Ethnicity

\begin{tabular}{lcccc}
\hline Statement & \multicolumn{3}{c}{ Mean } \\
& $\begin{array}{c}\text { Grand } \\
(\underline{\mathrm{N}}=49)\end{array}$ & $\begin{array}{c}\text { Yes } \\
(\underline{\mathrm{n}}=27)\end{array}$ & $\begin{array}{c}\text { No } \\
(\underline{\mathrm{n}}=22)\end{array}$ & F-Value \\
\hline Agriculture careers are for both men and women. & 3.58 & 3.85 & 3.27 & $13.11^{*}$ \\
A course in agriculture would be valuable to all & & & & \\
students. & 3.16 & 3.37 & 2.91 & $4.43^{*}$ \\
Agriculture careers pay well. & 2.82 & 3.07 & 2.50 & $6.86^{*}$ \\
Careers in agriculture are abundant. & 2.63 & 2.89 & 2.32 & $6.76^{*}$ \\
Agriculture is for people that live in rural areas. & 2.10 & 1.78 & 2.50 & $10.55^{*}$ \\
\hline
\end{tabular}

Note. Scale Values: 1 = Strongly Disagree; 2 = Disagree; 3 = Agree; 4 = Strongly Agree. $* \mathrm{p}<0.05$ 


\section{CHAPTER V}

\section{SUMMARY, CONCLUSIONS, AND RECOMMENDATIONS}

\section{Summary}

The purposes of this study were to assess the perceptions of high school teachers and students in Leflore County, Mississippi regarding agriculture, and to provide baseline data regarding the perceptions of agriculture high school students and teachers residing in an agriculturally dependent county with no agricultural education program. To accomplish these purposes, a population of 240 high school students and teachers were surveyed for their perceptions regarding agriculture.

A descriptive survey research method was used to collect data from high school students and teachers in Leflore County. Twelfth-grade classes at all three public high schools were surveyed independently in a "seminar-like" setting. The instrument used in this study was created by the researcher with the assistance of his graduate committee. The researcher personally administered the survey at each of the high schools.

The population for this census study was teachers and senior students from the three high schools in Leflore County: Amanda Elzy, Leflore County, and Greenwood. All three area high schools were chosen because of the researcher's interest in the entire population

of high school seniors in the two school districts. The two county schools (Leflore County and Amanda Elzy) are smaller schools and mostly rural. Greenwood High School is the largest school in the county, and it is mostly urban.

Two data collection instruments were developed based upon information gathered from related literature, which would provide data to meet the objectives of this study. The surveys were organized into two sections. Section I of the student's survey consisted of two parts; Part A was composed of statements which requested perceptions of students regarding agriculture on a four- point, Likert-type scale. Part B requested the student to write a short statement depicting his or her perception of agriculture. Section II of the survey inquired about demographic information, including gender, home location, ethnicity, and agriculture experience. The teacher's survey consisted of only Part A and Section II. 
Reliability means dependability, or trustworthiness. Basically, it is the degree to which a test consistently measures whatever it measures (Gay, 1996). The Cronbach alpha, or coefficient alpha, is widely used to measure the reliability of educational research instruments. A reliability score of 1.00 is an indication of a perfectly reliable instrument. In the reliability analysis conducted on the instrument used in this study, alpha equals 0.8478 .

All three public high schools in Leflore County were represented in this study. The population consisted of 240 participants, 188 students and 52 teachers. Females represented $65 \%$ of the population. Greenwood High School made up more than half of the entire population (52.5\%) and Leflore County (19.6\%) and Elzy (27.9\%) made up the remaining portion of the population. Greenwood High School had the most teachers to respond ( $\underline{n}=25)$, followed by Elzy ( $\underline{n}=22)$, and Leflore County ( $\underline{n}=5)$. Over $65 \%$ of the population resided in the city, while only $3 \%$ live on a farm. More than half (57\%) of the participants indicated that they had done agricultural related work, while $43 \%$ indicated that they had not. Over fifty percent of the respondents indicated that they had relatives that had been involved in agricultural related work. $49.1 \%$ of the population reported that they did not have any relatives involved in the agriculture industry. Ninety-two percent of the students and $51.9 \%$ of the teachers indicated that they were African Americans.

The first objective of this study was to assess the perceptions of high school teachers and students regarding agriculture. The population consisted of high school teachers and $12^{\text {th }}$ grade students enrolled in a Leflore County public high school during the 1998-1999 school year.

Similar to the findings of Kirts (1993), the participants in this study perceived the agricultural sector as consisting solely of production and farming. However, the results from the data analysis indicated that teachers and students possessed a positive perception of the agriculture industry. The participants agreed that they take pride in learning about the agricultural industry, and that they should be knowledgeable of the agricultural industry. Teachers and students in Leflore County thought that more people should appreciate the agricultural industry. 
Consistent with the findings in the study conducted by Mallory and Sommer (1986) the students in this study were unaware of the range of opportunities in agricultural careers. Teachers agreed that they were familiar with career opportunities available in agriculture. In contrast to Leising (1991), participants in this study did not perceive agricultural careers as boring, laborious work, and involving more muscle than brain. The participants' mean scores for individual perception statements regarding agriculture careers were considerably positive. They agreed that they possessed favorable perceptions of agriculture careers and the people in agricultural careers. The participants indicated a high level of agreement that agricultural careers were for both men and women.

Golloday (1994) suggested that students had at least two misconceptions about agriculture classes: agricultural occupations are for students with limited academic abilities and the second was that vocational agriculture is for someone else's child. Leflore County teachers and students rated individual perception statements regarding agriculture courses positively. The teachers and students agreed that a course in agriculture would be valuable to all students (college and non-college bound) and would help them to develop skills needed for employment in business and industry and competencies the needed for college.

Teachers and students in this study felt that students would have benefited from a course in agriculture and that all students should be required to take a basic agriculture course. They also possessed a high level of agreement that more emphasis should be placed on agriculture and that agriculture classes should be offered in their school.

Results from this study indicated that teachers and students, as a group, did not perceive their personal experiences, family history, or the media as a factor influencing their perceptions of agriculture. Majority of the respondents reported that they had not participated in an agricultural club or organization.

The second objective of this study was to compare the perceptions of teachers by school, gender, and ethnicity. Teachers in Elzy High School possessed the most positive perceptions of agriculture. They indicated a higher level of agreement that they had participated in an agriculture organization and perceived agriculture careers as being 
abundant. Male teachers thought that all students should be required to take a basic agriculture course.

The third objective of this study was to compare the perceptions of students by school, gender, and ethnicity. Students in Elzy and Greenwood High School perceived agriculture careers as being abundant. Only students in Greenwood High School felt that careers in agriculture are abundant. Male students possessed a higher perception than did female students. Males thought that they could have benefited from a course in agriculture, and that agriculture would have provided them with the competencies needed to succeed in college. They also perceived their family history as being a factor that influenced their perceptions. The representation of students from ethnic groups other than that of African American were relatively small; therefore, a comparison of students by ethnicity was not practical.

The fourth objective of this study was to determine the influence of selected variables on the perceptions of teachers and students regarding agriculture. Teachers who had done agriculture related work perceived their family history as being a factor that influenced their perceptions of agriculture. They felt strongly that more people should appreciate the agricultural industry. Teachers who had relatives that had done agricultural related work were more likely to have participated in an agriculture club. African American teachers perceived agriculture careers as being abundant, whereas teachers of other ethnicity did not.

Students who had done agricultural related work felt that they should be knowledgeable of the agricultural industry. Students who had relatives that had done agricultural related work indicated that they had a favorable perception of people in agriculture careers.

\section{Conclusion}

Agriculture is the very basis of civilization, so men and women of all ages and ethnic groups have a vested interest in agriculture. Since a vast majority of the population is more than one generation removed from agriculture, most Americans know little about food and fiber production, its social and economic significance in the United States, and its links to human health and environmental quality. Agriculture is Mississippi's number 
one industry, employing $30 \%$ of the state's workforce either directly or indirectly. Agriculture makes a significant contribution to all of the 82 counties in Mississippi especially Leflore County. Results of this study would lead one to conclude that:

- Teachers and students in Leflore County possessed a positive perception of agriculture.

- Teachers in Leflore County had a more favorable perception of agriculture than did students.

- Male teachers and students possessed a more favorable perception of agriculture and expressed more interest in agriculture than did female teachers and students.

- African American teachers possessed a more favorable perception of agriculture than teachers of other ethnic groups.

- Teachers and students who had done agricultural related work or had relatives who had done agricultural related work had a more favorable perception and expressed a greater interest in agriculture then the other teachers and students.

- Students in Leflore County had not participated in an agricultural club or organization.

- Male teachers and students and female teachers consider their personal and family history as factors influencing their perceptions of agriculture.

- Students in Leflore County are not planning to study or pursue a career in agriculture after high school.

The major finding of this study was that teacher and students perceived agriculture as being important and relative to their existence. Although a positive perception of agriculture exists among students, students have no intentions on studying or pursuing a career in agriculture.

\section{$\underline{\text { Recommendations }}$}

Based upon the findings of this research and review of literature, the following recommendations for Leflore County School System and future research studies:

- This study needs to be replicated in its complete or modified form to teachers and students nationwide to determine if the findings differ significantly from those in this study. A study in which the comparison of the perceptions among students entering 
and finishing high school should be conducted to see if a significant difference exists between the groups. This information would be helpful to further generalize the results on the basis of maturity.

- An agricultural program should be implemented into the curriculum of every high school in America. All students should be required to take a basic agriculture course. All teachers, but more specifically science teachers, should be trained and encouraged to use agricultural activities and examples in their lectures. Teachers should stress the importance of becoming involved in a variety of intra- and extracurricular activities, which promote agriculture and environmental awareness.

- Counselors should be encouraged to attend workshops on agricultural careers and post-secondary education curriculums. They should continue to encourage students to pursue agricultural related fields of study and occupations. Counselors and teachers need to be trained in helping students establish a positive attitude toward agriculture.

- Officials from the Mississippi's Land Grant Universities and the United States Department of Agriculture should be requested to sponsor workshops regarding agricultural literacy and careers. Students should be recruited and made aware of the educational and career opportunities in agriculture, in the early years of high school. They should also be encouraged and provide the opportunity to visit Land Grant Universities and participate in a variety of their sponsored events. Agricultural organizations in Leflore County should place more emphasis on recruiting students from the public school systems.

- Field trips to various types of farms and agriculture production facilities should be sponsored for students so that may become familiar with agricultural education, technology, production, and marketing as it exists today. Students should be made aware of how their skills and knowledge could be employed in agriculture. 


\section{REFERENCES}

Agricultural education on a roll in Georgia schools. (1990). Curriculum Review, $\underline{30}$, (1) 22 .

Agriculture census for Leflore County, Mississippi (1992). [On-line] Http://govinfo.library.orst.edu/.

Betts, S. I. \& Newcomb, L. H. (1986). High ability urban high school senior perception of agricultural study and selected recruitment strategies. National Association of Colleges and Teachers of Agriculture Journal, 30 (4), 14-17.

Birkenholz, R., Frick, N., Gardner, H. \& Machtmes, K. (1995). 4-H member knowledge and perception of agriculture. Journal of Agricultural Education, 36, (3) 4349.

Birkenholz, R., Frick, N., Gardner, H. \& Machtmes, K. (1995). Rural and urban inner-city high school student knowledge and perception of agriculture. Journal of Agriculture Education, 36, (4) 1-9.

Birkenholz, R., Frick, N., Gardner, H. \& Machtmes, K. (1995). Rural and urban adult knowledge and perceptions of agriculture. Journal of Agricultural Education, 36, (2) 4453.

Birkenholz, Robert J. (1996). The right change at the right time. Vocational Educational Journal, 71, (2) 43.

Cano, J. \& Bankston, J. (1992). Factors which influence participation and non participation of ethnic minority youth in Ohio 4-H programs. Journal of Agricultural Education, 33(1), 22-29.

Carter, R. L. \& Liebold (1987). Attitudes of students entering the colleges of agriculture, science and humanities. National Association of College and Teachers of Agriculture of Journal, 31 (4), 44-46.

Cole, L. (1985). Characteristics of those who select agricultural education as an undergraduate major at Oregon State University. The Journal of the American Association of Teacher Educators in Agriculture, 26 (3), 79-85. 
Findlay, H. J., \& Rawls, W. J. (1984). Factors that influence agricultural career objectives among students attending historically black four-year institutions. The Journal of the American Association of Teacher Educators in agriculture, 25 (1), 28-34.

Fobbs, Allen. (1942). Availability of vocational education in agriculture for Negroes in Mississippi.(Masters Thesis, Iowa State College).

Frick, M. (1991). A definition and the concepts of Agricultural literacy: A national study (doctoral dissertation, Iowa state University, 1990). Dissertation Abstracts International, 51, 2244A.

Golladay, M. A., \& Wulfsberg, R. M. (1981). Student choice of program. The condition of a vocational education, 187-196. Washington, DC: U.S. Department of Education, Center for Educational Statistics.

Grady, Thomas (1989). High School Students' Perception of Agriculture and careers in agriculture. [Critique]. Proceedings of the Sixteenth Annual National agricultural Education Research Meeting 156-157.

Higher Education Programs, USDA (1990). Employment opportunities for college graduates in the food and agricultural sciences. Washington, DC: U.S. Department of Agriculture, Higher Education Programs, Office of Grants and Program Systems.

Johnson, D. \& Newman, M. (1992). Perceptions of Administrators, guidance counselors, and science teachers concerning pilot agriscience courses. Proceedings of the Nineteenth Annual National Agricultural Education Research Meeting 1-9.

Johnson, D. \& Newman, M. (1992). Perceptions of Mississippi secondary agriculture teachers concerning pilot agriscience courses. Proceedings of the Nineteenth Annual National Agricultural Education Research Meeting 19-27.

Kirts, C. (1983). Alaska's hidden industry. Agricultural Education Magazine, 56, 13-15.

Krueger, D. E. \& S. R. Lierman (1990). Perceptions of administrators and instructors concerning factors influencing secondary agriculture enrollment. $\underline{\text { Journal of Agricultural }}$ Education, 31 (2), 7-11. 
Lancaster, L. \& Riesenberg, L. (1989). High school agriculture program completers and their success in college. Proceedings of the Nineteenth Annual National Agricultural Education Research Meeting 141-155.

Leising, J. (1991). A counseling tool for careers in agriculture. Proceedings of the Eighteenth Annual National agricultural Education Research Meeting 62-69.

Leising, J. (1991). Careers in agriculture as perceived by high school juniors and seniors. Proceedings of the Eighteenth Annual National Agricultural Education Research Meeting 62-69.

Mallory, M. \& Sommer, R. (1986). Student images of agriculture: Survey highlights and recommendations. Journal of The American Association of Teachers Education in Agriculture, 27(4), 15-17.

McGary, L. (1986). Proficiency winners survey report. The Agricultural Education Magazine, 59(2) 21.

Mississippi Agriculture at a Glance. [On-line]. Http://www.mdac.state.ms.us/agglance.htm.

Newsom-Stewart, M. \& Sutphin, H. (1994). How tenth grade students perceive agriculture and environmental science: Comparison by gender and ethnicity. Journal of Agriculture Education, 35, (3) 50-56.

Newsom-Stewart, M. \& Sutphin, H. (1994). Student's rationale for selection of agriculturally related courses in high school by gender and ethnicity. Journal of Agricultural Education, 36, (2) 54-62.

Nichols, T. and Nelson, C. (1993). Hispanics in agriculture: Barriers to educational recruitment. Proceeding of the Twentieth Annual National Agricultural Education Research Meeting, Nashville, TN.

Orgunride, S. I. (1981). Student knowledge of agricultural occupations upon enrollment in agricultural programs in Ohio joint vocational schools. (Doctoral dissertation, Ohio State University. Dissertation Abstracts International, 42-05A, 1909.

Orthel, G. R., Sorensen, J. L., Lierman, S. R. \& Riesenberg, L. E. (1989). High school Students Perceptions of Agriculture and Careers in Agriculture. Proceedings of the 16th National Agricultural Education Research Meeting. 
Orthel, G., Somensen, J., Lierman, S. \& Riesenberg, L.(1989). High school students' perceptions of agriculture and careers in agriculture. Proceedings of the Sixteenth Annual National agricultural Education Research Meeting 149-155.

Raven, Matt R. (1994). The need for Agriculture Literacy. Vocational Education Journal, 69, (3) 37.

Russell, E. \& Thompson, J. (1989). Beliefs and intentions of counselors, parents and students regarding agriculture as a career choice. Proceedings of the Sixteenth Annual national Agricultural Science Education Research Meeting 29-36.

Talbert, B. \& Larke A. (1993) Factors influencing minority and nonminority students to enroll in an introductory agriscience course in Texas. Proceedings of the Twelfth Annual national Agricultural Science Education Research Meeting.

Whitworth, Angie (1998). The importance of a good agricultural knowledge. [On-line]. Http:// www.wye.ac.uk/News/Issue1/Agricult/Agknow.html.

Woodard, J. \& Herren, R.(1995). Perceptions and practices of Georgia guidance counselors regarding agricultural education programs. Journal of Agricultural Education, 36, (2) 8-18.

Workforce Information, USDA (1997). USDA, Governmentwide Demographic Data. Washington, DC: U.S. Department of Agriculture, Office of Workforce Information.

Wright, Douglas E. (1994). Agricultural knowledge and perceptions of eleventh-grade students in out state Missouri schools. Journal of Agricultural Education, 35, (3) 50-55. 
APPENDICES 


\section{APPENDICES A}

Letter to the High School Principals 
February 23, 1999

Dear $<<$ Principal Name $>$ :

I am working toward my Master's Degree in Agriculture and Environmental Education at West Virginia University. As part of my course requirement, I wish to conduct a study to determine the perceptions of students and teachers regarding agriculture in Leflore County. I chose this topic because of the significance of the next generation's perception of agriculture.

As a graduate of Amanda Elzy High, Alcorn State University, and currently a United States Department of Agriculture employee, I am extremely interested in the image possessed by youth of the world's greatest industry. The image of students regarding the field of agriculture is critical to the future of agriculture. Assessing individual perceptions is the initial phase in addressing issues regarding increasing agriculture literacy and diversity in the agricultural industry.

The most critical part of my research is the collection of data by means of a survey. Your permission to conduct this study at your school is critical to the success of my thesis and addressing this important issue; therefore, I am requesting your permission to conduct the survey at your high school during the week of March 22 - 26.

During this time, I would administer the survey, then present a brief or extensive lecture to the high school seniors regarding agriculture. The study will involve only high school seniors and their teachers. The survey is expected to take approximately 15 - 20 minutes. Please let me know your preference of time spent conducting the seminar. If it is desired, I will provide you with a copy of the research survey, consent form and an outline of the seminar.

The primary objective of the seminar is to convey the importance of the agriculture industry and the numerous educational and career opportunities that are available. The seminar is titled the "Importance of the Agriculture Industry." The scope of this presentation includes topics regarding agriculture careers and education; resume writing and interviewing for agriculture careers; federal, state, and local agriculture agencies; and applying for college.

A consent/assent form and a cover letter will be issued to each of the students a week prior to the study. The students and their parents will be informed that the survey is voluntary, and that are no known or expected risks involved from participating in this study. Confidentiality of the information provided by the students and teachers in the survey will be maintained. In any publication that may result from this research, neither individual students nor teachers nor any information from which they might be identified will be published. 
A postcard and a self-addressed envelope are enclosed for the purpose of indicating whether or not I have your permission to administer the survey and conduct the seminar at your school.

Thank you for your time and cooperation. Your assistance is very important and greatly appreciated.

If you have any questions, please call me at United States Department of Agriculture, Natural Resources Conversation Service at (304) 291-4152, extension 142. If I am unavailable, please leave me a message and a convenient time for me to return your call.

Sincerely,

Ronald Howard

Graduate Student

Agriculture and Environmental Education West Virginia University
Dr. Layle D. Lawrence

Professor and Chair

Agricultural and Environmental Education West Virginia University

\section{Enclosures}


February 23, 1999

Ronald Howard,

College of Agriculture and Forestry

Box 6108, Room 2056

Morgantown, WV 26506-6108

Dear Ronald Howard:

I received your letter with regard to your interest in conducting a survey and seminar at << High School Name >> during the week of February 22-26, 1999.

- You have my permission to conduct your survey regarding the perception of agriculture possessed by students and teachers in Leflore County.

- You do not have my permission to conduct your survey regarding the perception of agriculture possessed by students and teachers in Leflore County.

- You have my permission to conduct a seminar concerning the importance of the agriculture industry.

- You do not have my permission to conduct a seminar regarding the importance of the agriculture industry.

- My preference for time spent conducting your survey and seminar is

- Comments - Listed below are my additional comments regarding your survey and seminar contents.

Sincerely,

$<<$ Principal Name $>$ 


\section{APPENDICES B}

Follow-up Letter to the High School Principals 
March 14, 1999

\section{Dear $<<$ Principal Name $>>$}

Thanks for your permission to administer my research survey and conduct a presentation regarding the importance of the agriculture industry at $<$ High School Name $\gg$. I am very grateful for being granted the opportunity to share my experiences and ideas with the students in my hometown.

Currently, I am scheduled to make presentations at Amanda Elzy, Leflore County, and Greenwood High School during the period of March 22 - 30, 1999. To finalize my itinerary, I need to verify a date and time that is most convenient to visit your school.

Please return the attached sheet (fax if possible) verifying that I have your permission to conduct my research at your high school so that it may be forwarded to West Virginia University Human Subjects Committee. Also, please indicate the date of your preference and the time allotment for the presentation (an hour and a half to two hours is preferable).

Thank you for your time and consideration. Your assistance is very important and greatly appreciated.

If you have any questions, please call me at (304) 291-4152, extension 142. If I am unavailable, please leave me a message and a convenient time for me to return your call.

Sincerely,

Ronald Howard

Graduate Student

Agriculture and Environmental Education

West Virginia University

Enclosures 
March 14, 1999

Ronald Howard,

USDA, NRCS

75 High Street, Room 301

Morgantown, WV 26505

Dear Ronald Howard:

I received your letter concerning your interest in conducting a research survey and presentation at $<<$ High School Name $>>$ during the period of March 22-30, 1999.

- You have my permission to conduct your survey regarding the perception of agriculture possessed by students and teachers in Leflore County.

- You do not have my permission to conduct your survey regarding the perception of agriculture possessed by students and teachers in Leflore County.

- You have my permission to conduct a presentation concerning the importance of the agriculture industry.

- You do not have my permission to conduct a presentation regarding the importance of the agriculture industry.

- The date that and time that is most convenient for my school is

- My preference for time spent conducting your survey and seminar is

- Comments - Listed below are my additional comments regarding your survey and seminar contents.

Sincerely,

$<<$ Principal Name $>>$ 


\section{APPENDICES C}

Cover Letter to Parents and Consent Form 


\section{PARENTAL or GUARDIAN CONSENT AND INFORMATION FORM}

\section{Perceptions of Students and Teachers Regarding Agriculture in Leflore County, Mississippi}

Introduction. I, , have been asked to allow my child

to participate in this study. Ron Howard, a graduate of Amanda

Elzy High School, is conducting this research to fulfill the requirements for a Master's thesis in Agricultural Education at West Virginia University. I have read his letter, which explains the study, to my child.

Purposes of the Study. The study is designed to determine perceptions of high school seniors regarding agriculture in Leflore County. Information may be used by school administrators in Leflore County in modifying or developing curriculum offered to students in the three high schools of the County.

Description of Procedures. The study will be performed at the high school my child attends. My child, along with his/her classmates, will be asked to rate a series of statements regarding his/her perceptions of the field of agriculture, which will take about 10 minutes to complete. If I wish, I can examine the questionnaire at the high school. All seniors in the school are being asked to participate in the study. Participants will not be asked to put their names on the questionnaires they complete.

Risks and Discomforts. There are no known or expected risks from participating in this study.

Benefits. I understand that this study is not expected to be of direct benefit to my child, but the knowledge gained may be of benefit to future students in the high school.

Contact Persons. For more information about this research, I can contact the principal or guidance counselor at my child's high school, or Dr. Lawrence, Mr. Howard's academic advisor at (304) 293-4832. For information about my child's rights as a research subject, I may contact the Executive Secretary of the Institutional Review board at West Virginia University at 293-7073.

Confidentiality. I understand that any information obtained as a result of my child's participation in this research will be kept as confidential as is legally possible. I understand that these research records, just like hospital records, may be subpoenaed by court order or may be inspected by federal regulatory authorities. My name or that of my child or any information from which we might be identified will not be published without my consent.

Voluntary Participation. Participation in this study is voluntary. I understand that I may withdraw my child from this study at any time. Refusal to participate or withdrawal will 
involve no penalty or loss of benefits for me or my child. I am free to ask questions about this research. Upon signing this form, I will receive a copy.

I willingly consent to my child's participation in this research.

$\overline{\text { Signature of parent or guardian }} \overline{\text { Date }}$ Time

$\overline{\text { Signature of investigator Date Time }}$ 


\section{APPENDICES D}

Cover Letter to Participants 


\section{Dear High School Senior,}

I am asking for your help in completing a study at West Virginia University. I am a graduate of Amanda Elzy High School (class of 1992), and am working toward my Master's degree at West Virginia University. As part of the completion of my thesis, I want to determine the perceptions of Leflore County seniors regarding agriculture and agriculture careers.

To complete my research, I am surveying seniors in the three high schools in Leflore County. I have asked your high school principal to allow me to meet with your class so that you can participate in the study.

Please get one of your parents or guardians to sign the Consent Form, then sign the Assent Form yourself so that you can take part in the study. It will take about 10 minutes of your time to complete the survey. We will simply ask you to express your agreement or disagreement with a series of statements regarding agriculture and agricultural careers. You will not be asked to put your name on the questionnaire that you complete. Of course, this is completely voluntary and you will in no way be penalized for choosing not to participate. Everything in the survey will be kept confidential, and if there are any questions that make you uncomfortable you do not have to answer them.

When all the surveys are completed, they will be analyzed to see what Leflore County seniors think about agriculture and agricultural careers. The results will be made available to school boards and administrators to assist them in future curriculum planning.

Thank you very much for your time and assistance. I certainly appreciate your cooperation. You will be helping me finish my degree as well as helping the school program to improve its curricular offerings.

Sincerely,

Ronald L. Howard

Graduate Student

West Virginia University 


\section{APPENDICES E}

Assent Form 


\section{ASSENT FORM \\ Perceptions of Students and Teachers Regarding Agriculture in Leflore County, Mississippi}

Introduction. I, , have been asked to be in this research study, which has been explained in a letter to me by Ron Howard, a graduate of Amanda Elzy High School in 1992.

Purpose of the Study. I have been told that the purpose of the study is to learn more about what seniors in Leflore County high schools think about agriculture.

Description of Procedures. This study will be performed at my high school. I will be given a list of statements about agriculture and will be asked to rate each one as to whether I agree or disagree with it. It will take about 10 minutes for me to answer the questions. I do not have to answer all the questions.

Discomforts. I may not enjoy trying to answer all the questions.

Benefits. I understand that this study is not expected to help me, but what they learn from the study may help future students in Leflore County high schools.

Confidentiality. I have been promised that anything they learn about me in this study will be kept as secret as possible. I will not be asked to put my name on the questionnaire that I complete.

Voluntary Participation. I have been told that I do not have to participate in this study. No one will be mad at me if I refuse or if I decide to quit. I have been allowed to ask my principal or guidance counselor questions about the research, and all of my questions were answered.

I willingly agree to be in this research.

$\overline{\text { Signature } \quad \text { Date }} \overline{\text { Time }}$

Signature of Investigator Date Time 


\section{APPENDICES F}

Teachers' Instrument 


\section{Section I:}

Rate each of the statements on a scale of one (1) to four (4) by filling in the appropriate box.

\begin{tabular}{|c|c|c|c|}
\hline 1 & 2 & 3 & 4 \\
Strongly Disagree & Disagree & Agree & Strongly Agree \\
\hline
\end{tabular}

\section{Please Select Only One!}

\begin{tabular}{|c|c|c|c|}
\hline Agriculture is essentially farming. & & & \\
\hline Agriculture careers are for mostly women. & & 2 & \\
\hline I have a favorable perception of agriculture careers. & & 2 & \\
\hline My personal experiences influenced my perception of agriculture. & & 2 & \\
\hline Agriculture careers pay well. & & 2 & \\
\hline More people should appreciate the agricultural industry. & 1 & 2 & \begin{tabular}{l|l|l}
3 & 4 \\
\end{tabular} \\
\hline $\begin{array}{l}\text { A course in agriculture would help students to develop skills needed for employment in } \\
\text { business and industry. }\end{array}$ & & 2 & \\
\hline Careers in agriculture are abundant. & & 2 & \\
\hline I take pride in learning about the agriculture industry. & & 2 & \\
\hline I have participated in an agriculture club (e.g., 4-H, FFA). & & 2 & \begin{tabular}{l|l}
3 & 4 \\
\end{tabular} \\
\hline Agriculture is for people live in rural areas. & & 2 & \\
\hline I have a favorable perception of people in agriculture careers. & & 2 & \\
\hline A course in agriculture would be valuable to all students. & & 2 & \\
\hline Agriculture careers are mostly for men. & & 2 & \\
\hline Agriculture classes in our school would benefit college prep students. & & 2 & \\
\hline My family history influenced my perception regarding agriculture. & & 2 & \\
\hline Agriculture careers are for both men and women. & & 2 & \\
\hline Students would benefit from a course in agriculture. & & 2 & \\
\hline There is not enough emphasis placed on agriculture in my school. & & 2 & \\
\hline Agriculture classes are primarily intended for the non-college bound student. & & 2 & \\
\hline All students should be required to take a basic agricultural course. & & 2 & \\
\hline I am familiar with career opportunities available in agriculture. & & 2 & \\
\hline Agriculture classes should be offered in my school. & & 2 & \\
\hline The media influenced my perception regarding agriculture. & 1 & 2 & \\
\hline I should be knowledgeable of the agricultural industry. & 1 & 2 & \begin{tabular}{|l|l}
3 & 4 \\
\end{tabular} \\
\hline $\begin{array}{l}\text { Agriculture classes would provide students with competencies they would need to } \\
\text { succeed in college. }\end{array}$ & & & \\
\hline Agriculture classes are primarily intended for the non-college bound student. & 1 & 2 & \begin{tabular}{|l|l}
3 & 4 \\
\end{tabular} \\
\hline $\begin{array}{l}\text { Parents of college bound students would be reluctant to have their children enroll in } \\
\text { agriculture classes. }\end{array}$ & & 2 & \\
\hline
\end{tabular}




\section{Section II:}

Please circle only one of the answers given!

A. Gender:

1. Male

2. Female

B. I teach the following subject(s):
1. Math
4. Business
7. Science
2. English
5. Music
8. Foreign Languages
3. History
6. Economics9. Other

C. My home is located on or in:

1. Farm

2. Town or rural non-farm area (e.g., Schalter, Sidon, Minter City)

3. City (e.g., Greenwood)

D. I have done some agriculture related work.
1. Yes
2. No

E. I have relative(s) that has a career in agriculture (e.g., agriculture education teacher, farmer).

1. Yes

2. No

F. Ethnicity:

1. African American

2. White American

3. Asian American

4. Hispanic American

5. Native American

\section{Comments:}

Please write additional comments here:

Thank you very much for answering the questions presented in this survey. Your participation in this research is greatly appreciated. 


\section{APPENDICES G}

Students' Instrument 


\section{Section I:}

Rate each of the statements on a scale of one (1) to four (4) by filling in the appropriate box.

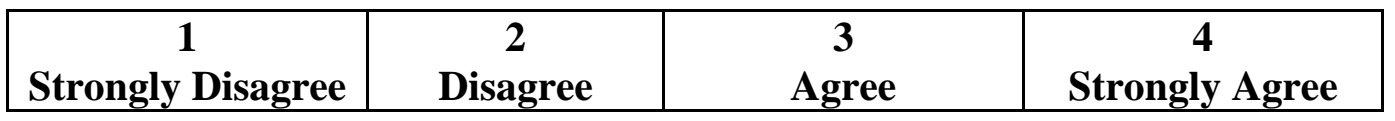

\section{Please Fill In Only One!}

\begin{tabular}{|c|c|c|c|c|}
\hline Agriculture is essentially farming. & 1 & 2 & $3 \mid$ & 4 \\
\hline Agriculture careers are for mostly women. & 1 & 2 & 3. & 4 \\
\hline I have a favorable perception of agriculture careers. & 1 & 2 & 3. & 4 \\
\hline My personal experiences influenced my perception of agriculture. & 1 & 2 & $3 \mid$ & 4 \\
\hline Agriculture careers pay well. & 1 & 2 & 3 & 4 \\
\hline More people should appreciate the agricultural industry. & 1 & 2 & 3. & 4 \\
\hline $\begin{array}{l}\text { A course in agriculture would have helped me to develop skills needed for } \\
\text { employment in business and industry. }\end{array}$ & 1 & 2 & 3 . & 4 \\
\hline Careers in agriculture are abundant. & 1 & 2 & 3. & 4 \\
\hline I take pride in learning about the agriculture industry. & 1 & 2 & 3. & 4 \\
\hline I have participated in an agriculture club (e.g., 4-H, FFA). & 1 & 2 & \begin{tabular}{l|l}
3 & \\
\end{tabular} & 4 \\
\hline Agriculture is for people live in rural areas. & 1 & 2 & 3. & 4 \\
\hline I have a favorable perception of people in agriculture careers. & 1 & 2 & 3 & 4 \\
\hline A course in agriculture would be valuable to all students. & 1 & 2 & 3. & 4 \\
\hline Agriculture careers are mostly for men. & 1 & 2 & 3. & 4 \\
\hline Agriculture classes in our school would benefit college prep students. & 1 & 2 & 3 & 4 \\
\hline My family history influenced my perception regarding agriculture. & 1 & 2 & 3 & 4 \\
\hline Agriculture careers are for both men and women. & 1 & 2 & 3 & 4 \\
\hline I would have benefited from a course in agriculture. & 1 & 2 & 3 & 4 \\
\hline There is not enough emphasis placed on agriculture in my school. & 1 & 2 & 3 & 4 \\
\hline Agriculture classes are primarily intended for the non-college bound student. & 1 & 2 & 3 & 4 \\
\hline All students should be required to take a basic agricultural course. & 1 & 2 & 3 & 4 \\
\hline I am familiar with career opportunities available in agriculture. & 1 & 2 & 3 & 4 \\
\hline Agriculture classes should be offered in my school. & 1 & 2 & 3 & 4 \\
\hline The media influenced my perception regarding agriculture. & 1 & 2 & 3 & 4 \\
\hline I should be knowledgeable of the agricultural industry. & 1 & 2 & 3 & 4 \\
\hline $\begin{array}{l}\text { Agriculture classes would provide me with competencies I would need to succeed } \\
\text { in college. }\end{array}$ & 1 & 2 & 3 & 4 \\
\hline Agriculture classes are primarily intended for the non-college bound student. & 1 & 2 & 3 & 4 \\
\hline My parents would be reluctant to allow me to enroll in agriculture classes. & 1 & 2 & 3 & 4 \\
\hline Agriculture is not for me. & 1 & 2 & 3 & 4 \\
\hline Agriculture is important to my community. & 1 & 2 & 3 & 4 \\
\hline Agriculture is important to my state. & 1 & 2 & 3 & 4 \\
\hline
\end{tabular}




\begin{tabular}{|c|c|c|c|c|}
\hline Agriculture careers require more muscle than brain. & 1 & 2 & 3 & 4 \\
\hline I am considering a career in agriculture. & 1 & 2 & 3 & 4 \\
\hline The agriculture industry interests me. & 1 & 2 & 3 & 4 \\
\hline Agriculture careers are boring. & 1 & 2 & 3 & 4 \\
\hline My teachers stress the importance of agriculture. & 1 & 2 & 3 & 4 \\
\hline My family stresses the importance of agriculture. & 1 & 2 & 3 & 4 \\
\hline My friends have expressed interest in agriculture. & 1 & 2 & 3 & 4 \\
\hline I may study agriculture after high school. & 1 & 2 & 3 & 4 \\
\hline I have no interest in studying agriculture. & 1 & 2 & 3 & 4 \\
\hline
\end{tabular}




\section{Section II, A:}

Please circle only one of the answers given!

\section{Section II:}

Please circle only one of the answers given!

A. Gender:

1. Male

2. Female

B. My favorite subject(s) is/are:
1. Math
4. Business
7. Science
2. English
5. Music
8. Foreign Languages
3. History
6. Economics
9. Other

C. My home is located on or in:

1. Farm

2. Town or rural non-farm area (e.g., Schalter, Sidon, Minter City)

3. City (e.g., Greenwood)

D. I have done some agriculture related work.
1. Yes
2. No

E. I have relative(s) that has a career in agriculture (e.g., agriculture education teacher, farmer).

1. Yes

2. No

F. Ethnicity:

1. African American

2. White American

3. Asian American

4. Hispanic American

5. Native American

\section{Section II, Part B:}

Please write a few sentences regarding your perception of agriculture.

Thank you very much for answering the questions presented in this survey! Your participation in this research is greatly appreciated! 


\section{APPENDICES H}

Teachers' Comments 


\section{Teachers' Comments}

- A course in agriculture will be beneficial both for male and female students.

- I do not appreciate having to answer this in the middle of a lesson I was teaching.

- You may want to also tie in botany or gardening questions into the survey.

- The country should do more to support farmers.

- With such an emphasis on the college prep curriculum, I doubt if many students have time for an agriculture course.

- Students would benefit from a course in agriculture in as much as education in any subject would be welcome. They do not know much about agriculture despite living in a major agricultural area. Whether this course is for college-bound kids depends entirely on how it is taught. It should have academic as well as vocational components, and it should include an analysis of agriculture 's occasional social responsibility (e.g., pesticide problems, exploration of migrant farm workers, etc.)

- I have taken a few agriculture careers at Mississippi State.

- All students should learn the economic status of agriculture. Yes, we need agriculture in our curriculum.

- I am interested in nature, therefore; I have high perceptions of agriculture.

- We should instill pride in our students related to farming. There is too much negative reaction to farming. 


\section{APPENDICES I}

Students' Comments 


\section{Students' Comments}

- I think that agriculture is a good field for those who have an interest in it. It is important to our country.

- Agriculture should be available in every school. Agriculture sounds really interesting. Agriculture should play an important role in everyone's life.

- I do not think agriculture is essential to my education.

- I do not have a perception about agriculture because it is not being taught in my school.

- Agriculture is a very good subject to study. People can learn a lot from agriculture. Agriculture has a lot to do with our environment. Without agriculture our nature's balance would change and be all twisted up. I am glad that someone is taking interest in agriculture.

- I am not interested in agriculture.

- I really do not have a perception of agriculture because I am not very familiar with it.

- Truly, I would like to have a career in agriculture, but I have no interest in agriculture at all. Agriculture is a good subject to study.

I really have no concerns with agriculture; furthermore, I have nothing to say.

- I am not interested in agriculture. Agriculture is boring to me. You really do not have to have a college degree for agriculture.

- I believe agriculture is very significant to our environment. Agriculture is a vast subject that should be elaborated on more.

- I have no comments about my perception of agriculture.

- Agriculture is for small towns that have nothing else to do.

- I really do not like agriculture, but it is great for the people who want to study it. It's great money!

I think agriculture is very productive in my state.

- I do not feel agriculture is important to me. It is important to those who love the rural life. I do not like rural life.

- I do not have an interest in agriculture. What I want to do is not related to agriculture. 
- I could reconsider majoring in an agricultural related field, but our school lacks an agriculture class. Therefore, I do not know much about it.

- I think that agriculture is very important. I think that schools should express the importance agriculture more.

- Agriculture is very important to society. More people should be knowledgeable about agriculture and careers in this field.

- Agriculture is very important in society. Without it, we would not have the necessities for life.

- Its ok, but I would like to pursue a career in teaching.

- Agriculture is not the most exciting field, but it is a necessity. Today, careers in agriculture are becoming more and more abundant.

- There is nothing wrong with agriculture. I just do not want to be involve with it. I want to be a nurse or a teacher.

- Agriculture is necessary to maintain a well-balanced economy.

- My grandfather is employed by the agricultural industry.

- Agriculture deals with farming. If agriculture did not exist, there would not be any food. Therefore, I think that it is good.

- I perceive agriculture as a growing field. It benefits our lives every day.

- I think agriculture is a good career, it has many benefits for the land of Mississippi and other agriculture counties.

- I think it is very important to our economy. We have a more of a natural work environment.

- I mainly think of agriculture as farming. However, I know there is more to it than that.

- I think that it is not well known, but a very needed industry.

- Agriculture to me seems like it is farming work and is boring. I have not had any prior experience in agriculture, and do not really think about it.

- I have nothing against agriculture, but I am not interested in studying it.

- Agriculture is very important in my community. The Delta depends heavily upon it. Agriculture is a career that is growing rapidly. I would like to have more information about how it can help me. 
- If you are a person that loves to beautify the land around you, then I feel that majoring in an agricultural is the career for you.

- Agriculture is mainly farming and it is passed down through generation by tradition.

- I think agriculture is very important to our economy, society, and is a way of survival for others.

- Agriculture is a very interesting subject and can actually be well utilized in many sources.

- Agriculture careers look boring.

- I feel that agriculture will help many people advance in life.

- I do not know that much about agricultural careers because it's not emphasized anywhere I go.

- A lot of people need to be involved in agriculture, mainly because this is our earth and we need to keep it clean.

- I feel that agriculture is a good course for people who have an interest in farming

- I do not know anything about agriculture.

- I think that agriculture is very important to our everyday life, but I am just not interested in it.

- I am not interested in agriculture.

- It is ok if you want a job that pays well.

- Agriculture is important to the town that I live in, but it does not interest me.

- Agriculture is a good major. It is something you have to really want to do. You can get paid well from it also.

- I would not mind going to college to major in agriculture.

- Agriculture is an ok career, and it is not all about farming or driving tractors, but you can go into other agricultural courses or fields. But I do not see myself doing it for a living.

- I do not know much about agriculture.

- I had a job that was related to agriculture.

- An agriculture career is not for me. I do not plan to become involved in such a career. 
- I think agriculture is important. It is important because if farmers did not plant their crops, then we would not food or clothing.

- I do not know much about agriculture, but I am willing to learn.

- Agriculture is a great part of our state. It is one of the major businesses around. Without agriculture, we would not have a lot of things.

- I do not know anything about agriculture.

- I do not know anything about agriculture but it concerns grass and flowers and maybe how they grow, where they grow, why or why they do not grow in a certain area.

- I really have not considered any aspects of agriculture as a career, because I have not really thought about it.

- I think that agriculture is a great career but it not for me.

- I have a very narrow perception of agriculture. However, I feel that agriculture is very beneficial towards the economic growth in the United States.

- I do not know anything about this subject.

- I have no interest in agriculture, and also, I do not know too much about agriculture.

- Agriculture is greatly needed and all students should have some knowledge of what it is, and why it is needed.

- Thank you for taking time out of your schedule to come and give us this survey; However, I plan to become a lawyer.

- I think that agriculture is important but it is not something I would be interested in.

- I really can not write much about agriculture, because I do not know much about it.

- Agriculture affects everybody. We depend on this industry for food as well as clothing. Many people are turned off by this subject because they are either misinformed or uneducated about it. People cringe at the thought of being a farmer.

- I think agriculture is important. I do not think that I would want to pursue a career in it.

- I really do not know that much about agriculture, but I would be willing to learn something about in. 
- I think agriculture is a nice subject to study, but I really do not have an interest in majoring in it. I strongly support the people who are interested in this area and hope they will serve us well.

- Agriculture is the heart of the United States.

- I think that agriculture would make a great career.

- I am a strong participant in agriculture. I was raised on a farm, and I have worked on a farm all my life. Some of my relatives are farmers.

- I really do not know much about agriculture, but I do think it may be a good field for some people.

- I think that agriculture as the study of the earth - growing things, taking care of the soil, and planting crops.

- People who like to farm, plant, etc., should major in this.

- I really do not know much about agriculture, but I am sure that it is a good field to study.

- It is a great field to go into. I love farm life, but it is not for me. But I do feel people should take more interest in agriculture. It is the main reason for our livelihood. 


\section{VITA}

Ronald Leon Howard was born February 23, 1974, in Leflore County, Mississippi. He was the third born to Ms. Virginia Howard. He began his education at Amanda Elzy Elementary School. He earned his diploma from Amanda Elzy High School in May 1992. He was accepted to Alcorn State University located in Lorman, MS in Fall 1992. In May 1997, Ronald earned his Bachelor of Science Degree in Agriculture Economics from ASU.

During the summer of 1995 and 1996, Mr. Howard was employed by the United States Department of Agriculture, Natural Resources Conservation Services as a summer intern student. He served as Geographical Information System Aide for the East Region Manuscript Office. He was admitted to graduate school at West Virginia University in May of 1997. Ronald is a candidate for a Master of Science degree in Agricultural and Environmental Education. He is now employed by the USDA, Natural Resources Conservation Service as a Soil Conservationist in Martinsburg, West Virginia. 